\title{
Utilização de Ontologias para Busca em Base de Dados de Acórdãos do STF
}

\author{
Rafael Brito de Oliveira
}

\author{
DisSERTAÇÃO APRESENTADA \\ $\mathrm{AO}$ \\ Instituto De Matemática e Estatística \\ DA \\ Universidade DE SÃo PAUlo \\ PARA \\ OBTENÇÃO DO TÍTULO \\ $\mathrm{DE}$ \\ Mestre em Ciências da ComputaÇão \\ Programa: MAC \\ Orientador: Profa. Dra. Renata Wassermann
}




\section{Utilização de Ontologias para Busca em Base de Dados de Acórdãos do STF}

Esta é a versão original da dissertação elaborada pelo candidato (Rafael Brito de Oliveira), tal como submetida à Comissão Julgadora. 


\section{Agradecimentos}

Primeiramente aos meus pais Luiza Brito de Oliveira e Florisvaldo Manoel de Oliveira, por sempre terem me dado todo o apoio necessário e a minha esposa Nataly Giacomini. Também gostaria de agradecer imensamente ao Prof. Juliano Maranhão e seus alunos Bruna de Bem, Jorge Alberto Araújo e Marina Arvigo, sem vocês esse trabalho não teria sido possível, obrigado pelo tempo dispensado em me ajudar com as questões de cunho jurídico. 


\section{Resumo}

DE OLIVEIRA, R. B. Utilização de Ontologias para Busca em Base de Dados de Acórdãos do STF. 2017. 58 f. Dissertação (Mestrado) - Instituto de Matemática e Estatística, Universidade de São Paulo, São Paulo, 2017.

O Supremo Tribunal Federal (STF) mantém uma base de documentos que relatam suas decisões tomadas em todos os julgamentos passados. Esses documentos são chamados de acórdãos e compõem a jurisprudência do STF, pois abordam assuntos que dizem respeito a constituição. Eles estão disponíveis a todos, porém encontrar uma informação relevante é uma tarefa árdua, que muitas vezes exige um nível de conhecimento da área jurídica.

O STF oferece um mecanismo de busca para esses acórdãos, porém o mecanismo atual utiliza uma forma tradicional de busca baseado em formulários com inúmeros campos a serem preenchidos e selecionados, se assemelhando a um questionário, no qual cada pergunta está relacionada a filtragem de certas informações em toda a base persistida em bancos de dados relacional. Esta abordagem do ponto de vista do usuário é pouco intuitiva e em alguns casos imprecisa.

Com base nesta dificuldade, neste trabalho é apresentada uma abordagem de um mecanismo de pesquisa que utiliza uma ontologia para a criação de uma representação do conhecimento contido nos acórdãos do STF. Sua construção é feita com o auxílio da tecnologia OBDA (Ontology Based Data Access), que permite a criação de uma camada semântica sobre uma base de dados relacional, o que possibilita a realização de consultas em SPARQL.

Palavras-chave: ontologia, OBDA, acórdão, SPARQL, STF 


\section{Abstract}

DE OLIVEIRA, R. B. Using an Ontology for Searching the Decisions of the Brazilian Supreme Court. 2017. 58 f. Dissertação (Mestrado) - Instituto de Matemática e Estatística, Universidade de São Paulo, São Paulo, 2017.

The Brazilian Supreme Federal Court (STF) keeps in its database documents describing past judgments decisions. This documents are called acórdãos (decisions) and are part of STF jurisprudence because they deal with matters that concern the Federal Constitution. They are publicly available, but finding relevant information is often requires a high level of knowledge about the juridical area.

The STF offers a search mechanism for the acórdãos, but through a form with a lot of fields to be filled, looking like a questionnaire, where each question is related with certain filtered data persisted over the relational database. This approach from user's perspective, is unintuitive and in some cases inaccurate.

For this reason, this work presents an approach where the search mechanism is based on an ontology that represents the knowledge inside the STF acórdãos. Other technology used here is the OBDA (Ontology Based Data Access), that allows the use of an abstract semantic layer over a relational database, and with it is possible to query the database with SPARQL.

Keywords: ontology, OBDA, decision, SPARQL, STF 


\section{Sumário}

$\begin{array}{ll}\text { Lista de Abreviaturas } & \text { ix }\end{array}$

Lista de Figuras

Lista de Tabelas $\quad$ xiii

1 Introdução $\quad 1$

1.1 Motivação . . . . . . . . . . . . . . . . . . . . . . . . 5

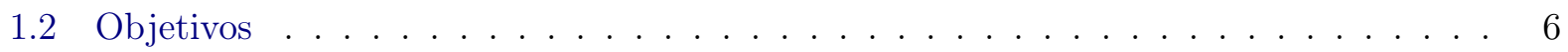

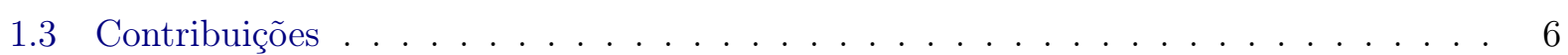

1.4 Organização do Trabalho . . . . . . . . . . . . . . . . . . . . . 6

$\begin{array}{lll}2 & \text { Conceitos } & 7\end{array}$

2.1 Ontologias . . . . . . . . . . . . . . . . . . . 7

2.2 Tipos de Ontologias . . . . . . . . . . . . . . . . . . . . . 7

2.3 Construção de Ontologias . . . . . . . . . . . . . . . . . . . . . . . 8

2.4 Metodologia para Construção de Ontologias . . . . . . . . . . . . . . . . 8

2.5 Ferramentas para Construção de Ontologias . . . . . . . . . . . . . . . . . . . . 9

2.6 Padrões para Representação de Ontologias . . . . . . . . . . . . . . . . . . . . 10

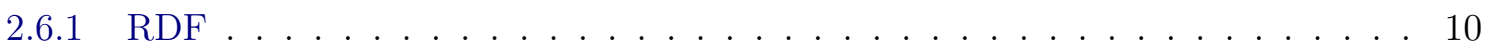

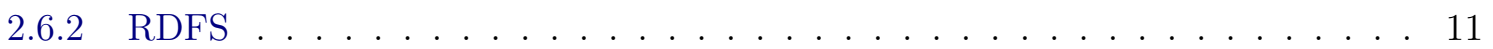

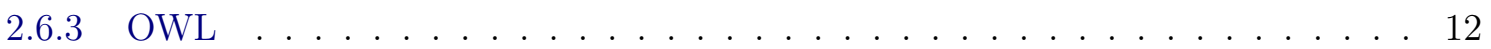

2.6 .4 OWL $2 \ldots \ldots \ldots \ldots \ldots$

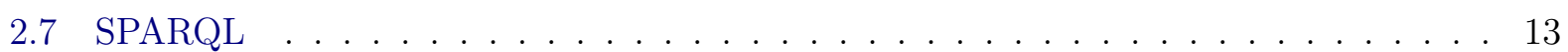

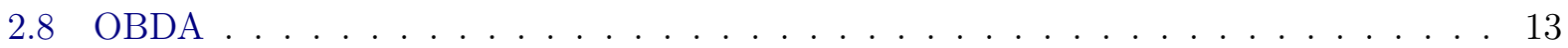

2.8 .1 O Framework Ontop . . . . . . . . . . . . . . . . . . . . . 14

3 Trabalhos Anteriores $\quad 15$

3.1 Obtendo os Acórdãos do STF . . . . . . . . . . . . . . . . . . . 15

3.2 Reutilização de uma Ontologia do Domínio Jurídico . . . . . . . . . . . . . . . . 16

4 Metodologia de Desenvolvimento $\quad 19$

4.1 Identificação das Entidades e Relações da Ontologia . . . . . . . . . . . . . . . . . . 19

4.1.1 Treinamento e classificação das Decisões dos Acórdãos . . . . . . . . . . . . . 20

4.2 Construção da ontologia . . . . . . . . . . . . . . . . . . . . . . . . . 21

4.2 .1 Formalização da Ontologia . . . . . . . . . . . . . . . . . . . . . 22 
4.2 .2 Criação das Propriedades de Objeto . . . . . . . . . . . . . . . . . . 23

4.2 .3 Criação das Propriedades de Dados . . . . . . . . . . . . . . . . . . . 23

4.2 .4 Mapeamento com OntoP . . . . . . . . . . . . . . . . . . . 23

4.2 .5 Validação da Ontologia . . . . . . . . . . . . . . . . . . 26

5 Construção do Mecanismo de Consulta $\quad 29$

5.1 Arquitetura do Mecanismo de Consulta . . . . . . . . . . . . . . . . . . . . . . . . . 29

5.1 .1 Módulo de Interface do Usuário . . . . . . . . . . . . . . . . . . . . . 30

5.1 .2 Módulo de Aplicação . . . . . . . . . . . . . . . . . . . . . . . . . . . . 30

5.1 .3 Módulo de Ontologia . . . . . . . . . . . . . . . . . . . . . . . . 31

6 Resultados 33

6.1 Pesquisa de Jurisprudência . . . . . . . . . . . . . . . . . . . . . . 33

6.2 Mecanismo de Busca do STF . . . . . . . . . . . . . . . . . 35

7 Conclusões $\quad 39$

Referências Bibliográficas $\quad 41$ 


\title{
Lista de Abreviaturas
}

\author{
STF Supremo Tribunal Federal \\ STJ Supremo Tribunal de Justiça \\ TJ Tribunal de Justiça \\ XML Extensible Markup Language \\ RDF Resource Description Framework \\ RDFs Resource Description Framework Schema \\ SPARQL Simple Protocol and RDF Query Language \\ OWL Web Ontology Language \\ OBDA Ontology Based Data Access
}




\section{Lista de Figuras}

1.1 Acórdão em seu inteiro teor . . . . . . . . . . . . . . . . . . . . . . . 3

1.2 Mesmo acórdão da Figura 1.1 mas em uma versão resumida . . . . . . . . . . . . . . 4

1.3 Interface atual de busca do STF . . . . . . . . . . . . . . . . . . . 5

2.1 Diagrama de atividades da metologia proposta por [Guizzardi, 2000]. Fonte da imagem [Morais e Ambrósio, 2007]. . . . . . . . . . . . . . . . . . . . . 10

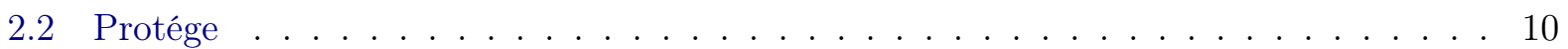

2.3 Exemplo de tripla em RDF . . . . . . . . . . . . . . . . . . . 11

2.4 Processo de transformação de consulta em um sistema OBDA [Bagosi et al., 2014] . 14

3.1 Modelo de dados da base relacional criada . . . . . . . . . . . . . . . . . . . . 17

3.2 JurisJFES - ontologia proposta por [Bourguet e Costa, 2016] . . . . . . . . . . . 17

4.1 Exemplo de uma decisão de um Acórdão . . . . . . . . . . . . . . . . . . . . 20

4.2 JurisJFSP - ontologia adaptada para este trabalho . . . . . . . . . . . . . . 22

4.3 Hierarquia de classes da ontologia no domínio dos acórdãos do STF . . . . . . . . . . 22

4.4 Hierarquia de classes da ontologia no domínio dos acórdãos do STF . . . . . . . . . . 23

4.5 Aba de definição de tipo de dado do Protégé . . . . . . . . . . . . . . . . . . . . 24

4.6 Aba do OntoP para criação do datasource . . . . . . . . . . . . . . . . . . . . 24

4.7 Aba do OntoP para gerenciamento dos mapeamentos . . . . . . . . . . . . . . . 25

4.8 Aba do OntoP de assistência para criação dos mapeamentos . . . . . . . . . . . . . 26

4.9 Mapeamento que define o atributo ID da tabela CLASSE_PROCESSO como uma Classe de Processo do tipo ADI . . . . . . . . . . . . . . . . . . . 26

4.10 Mapeamento que define o relacionamento entre um Acórdão e uma Classe de Processo

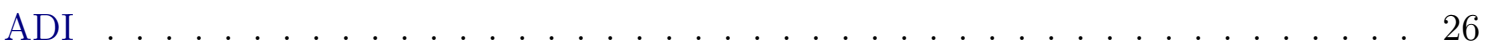

4.11 Mapeamento que define o atributo ID da tabela DECISAO como uma classe do tipo Decisao. Também são definidos as propriedades de dados "classificação"e "descrição" 26

4.12 Consulta em SPARQL para a questão Quais ministros são desafiados? . . . . . . . . 27

4.13 Consulta em SPARQL para a questão: Quais ministros são desafiadores? . . . . . . . 27

4.14 Consulta em SPARQL para a questão: Quais ministros enquanto relatores dão provimento para ação direta de inconstitucionalidade? . . . . . . . . . . . . . . . . . . 28

5.1 Arquitetura do mecanismo de busca para os acórdãos do STF utilizando ontologia 29

5.2 Consulta em SPARQL para a questão de competência "Quais ministros são desafiados?" . . . . . . . . . . . . . . . . . . . . . . . 31 
6.1 Resultado para questão "Quais ministros são desafiados?" . . . . . . . . . . . . . . . 33

6.2 Resultado para a questão "Quais ministros são desafiadores?" . . . . . . . . . . . . . . . 34

6.3 Resultado para a questão "Quais ministros do STF, enquanto relatores, dão provimento sim para ações diretas de inconstitucionalidade?" . . . . . . . . . . . . . . . . 34

6.4 Acesso link direto para um Acórdão . . . . . . . . . . . . . . . . . . . . 35

6.5 Mecanismo de busca do STF. Consulta: Quais ministros são desafiados? . . . . . . . 35

6.6 Resultado da busca utilizando mecanismo do STF . . . . . . . . . . . . . . . . 36

6.7 Acórdão contendo ministro no papel de Relator para Acórdão . . . . . . . . . . . . . 36

6.8 Acórdão parte do resultado de ministros desafiados mas que não contêm Relator para

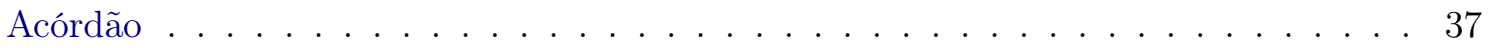




\section{Lista de Tabelas}

4.1 Questões de competência . . . . . . . . . . . . . . . . . . . . . . . 19

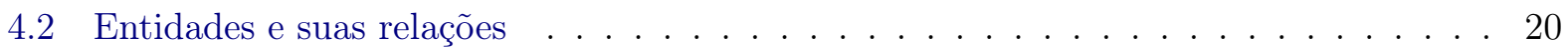

4.3 Tipos de decisões contidadas nos Acórdãos . . . . . . . . . . . . . . . . . . . . . . . . 21 


\section{Capítulo 1}

\section{Introdução}

O sistema jurídico romano-germânico, baseado no Direito Romano, constitui-se de um Direito no qual há primazia da lei e a tendência à codificação, sendo relegado aos juízes papel secundário. Diferencia-se do sistema anglo-saxão, Common Law, em que as normas gerais são inferidas a partir de decisões judiciais proferidas a respeito de casos individuais.

No Brasil, o Supremo Tribunal Federal (STF) é o órgão de cúpula do Poder Judiciário, sendo competente para manter o respeito à Constituição em todo o país. É composto por 11 ministros, escolhidos dentre cidadãos com mais de trinta e cinco e menos de sessenta e cinco anos de idade, de notável saber jurídico e reputação ilibada. Seus integrantes são nomeados pelo Presidente da República após a aprovação pela maioria absoluta do Senado Federal [Cintra et al., 2006].

A literatura [Falcão et al., 2011] delineia o STF como três personas distintas, todas com sua competência determinada pela Constituição Federal: (i) instância máxima do Poder Judiciário, no qual exerce o controle difuso de constitucionalidade, (ii) Tribunal originário para o controle concentrado de constitucionalidade, e (iii) Corte competente para o julgamento de infrações penais comuns e crimes de responsabilidade de Ministros de Estado e Comandantes das Forças Armadas.

Sobre as questões constitucionais debatidas no STF, descreve o Supremo em Números:

(...) As questões constitucionais chegam ao tribunal em, no mínimo, dois contextos institucionais diferentes: i) em controle concentrado e abstrato, onde o Supremo faz a primeira e última análise sobre a questão constitucional em exame, sendo um modelo de instância única; ii) em controle difuso e concentrado, onde o STF faz apenas a última análise das questões constitucionais, questões estas que tipicamente chegam ao tribunal por meio de recursos e que já tiveram sua constitucionalidade analisada por pelo menos um juiz inferior. É, então, um modelo de múltiplas instâncias.

O controle abstrato de constitucionalidade analisa a compatibilidade de atos normativos em tese com a Constituição, o que significa dizer que não são julgados casos concretos, mas sim o ato normativo em si. Diferentemente do que ocorre com o controle difuso, em que os efeitos do julgado são interpartes, no controle abstrato há efeito erga omnes, ou seja, contra/obriga a todos. As ações passíveis de análise por meio do controle abstrato de constitucionalidade são:

- Ação Declaratória de Constitucionalidade (ADC)

- Ação Direta de Inconstitucionalidade (ADI)

- Ação Direta de Inconstitucionalidade por Omissão (ADO)

- Arguição de Descumprimento de Preceito Fundamental (ADPF)

- Mandado de Injunção (MI) 
- Proposta de Súmula Vinculante (PSV)

Dentre estas a que mais se destaca é a ADI. Esta é a ação na qual se pretende determinar que um ato normativo (em termos gerais, uma lei) se encontra em descompasso com a Constituição Federal, sendo necessária sua retirada do ordenamento jurídico. Uma vez declarada a inconstitucionalidade de um ato normativo pelo Supremo Tribunal Federal, deve ${ }^{1}$ o Senado Federal suspender a execução de tal ato.

Em todos os casos que chegam ao STF, mas principalmente nas ADIs, o protagonista da ação é o relator. Ao "senhor do processo" [Silva, 2015], determinado por sorteio dentre os Ministros. O papel do Relator é fundamental, pois além de caber a ele a condução do caso durante toda a tramitação na Corte, desde o recebimento, até a liberação do feito para julgamento, salvo exceções em que é vencido, é dele também a responsabilidade de analisar profundamente todos os altos, realizar diligências, apresentar o caso aos demais Ministros do tribunal e dar o primeiro voto no julgamento. Na maioria dos casos, é esperado que o voto do Relator, por ser quem possui maior conhecimento sobre o caso, dê o voto condutor e que o mesmo seja seguido pelos votos dos demais Ministros. Existem casos, porém, em que o posicionamento do relator é derrotado pela maioria dos Ministros. Nestes casos, surge então o papel do Relator para acórdão que é assumido pelo primeiro Ministro a dar um voto divergente ao do relator original.

Ao final de todo julgamento, o Relator original ou o Relator para acórdão, ficam encarregados de redigir um relatório final, que é então arquivado, indexado e recebe o nome de acórdão. Os acórdãos do STF contêm informações detalhadas dos julgamentos realizados em última instância. A Figura 1.1 demonstra a estrutura de um acórdão, que se descreve por meio de suas cinco partes:

- Primeira Parte: contém os dados do processo que originou a decisão do acórdão. Essa área possui informações como o colegiado julgador do processo, sua classe jurídica e os autores e réus do mesmo. Além disso, também contém informações cruciais dos recursos, que detalham por exemplo o que levou ao reexame da decisão dada.

- Segunda Parte: contém a ementa do acórdão. A ementa é um resumo do julgamento, contendo o assunto do processo, palavras chaves que o descrevem e os pressupostos utilizados para a decisão.

- Terceira Parte: é o acórdão propriamente dito. Esse é um parágrafo que contém o quórum do julgamento, descrito com seus respectivos papéis e a decisão final. A data do julgamento e a assinatura do relator também fazem parte deste parágrafo.

- Quarta Parte: é o relatório, onde o ministro relator descreve os eventos e pressupostos do processo. São expostos o evento, a decisão do primeiro grau, o histórico da ação e eventuais interposições de autoridades externas. O relatório é a forma por meio da qual os ministros que não tiveram acesso ao processo tomam conhecimento da causa.

- Quinta Parte: é onde são expostos os votos dos ministros e por fim, apresenta uma breve repetição do acórdão registrada ao final do documento com o objetivo de suceder-se à discussão do colegiado.

O direito pode ser entendido como um sistema dinâmico [Sampaio, 2015], em constante mudanças perante a sociedade e por isso um dos principais motivos de interesse pelos acórdãos é por serem uma fonte de pesquisa e de extração de informações úteis para julgamentos futuros. Um advogado pode por exemplo querer saber quem são os Relatores que recorrentemente são mais desafiados, ou seja que têm o seu voto vencido. Através desta informação é possível ter uma perspectiva sobre o rumo de um julgamento dado um determinado Relator. Somando-se a este tipo de questionamento,

\footnotetext{
${ }^{1}$ Há controvérsias no campo jurídico acerca do dever de acatar ou poder de não confirmar, por parte do Senado Federal, as decisões de inconstitucionalidade do Supremo Tribunal Federal. Não sendo este o foco do presente trabalho, tal questão não será aprofundada neste momento
} 
outros mais, vemos que ter acesso ao histórico de todos os julgamentos é de extrema importância, tanto para os profissionais da área jurídica, no exercício de suas funções quanto para todo e qualquer cidadão.

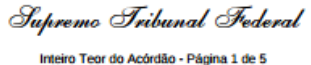

$18 / 12 / 2013$
SEgunda TURma

AG.reg. NO ReCurSo Extraordinário 559.650 Mato Grosso

\begin{tabular}{|c|c|}
\hline RELATOR & : MIN. TEORI ZAVASCKI \\
\hline AGTE.(s) & :BANCO DO BRASIL S/A \\
\hline ADV.(A/s) & :JORGE ELIAS NEHME E OUTRO(A/S) \\
\hline AGDO.(A/s) & :MUNICIPIO DE ALTA FLORESTA \\
\hline Proc.(A/S)(ES) & $\begin{array}{l}\text { :PROCURADOR-GERAL DO MUNICÍPIO DE ALTA } \\
\text { FLORESTA }\end{array}$ \\
\hline
\end{tabular}

EMENTA: CONSTITUCIONAL. RECURSO EXTRAORDINÁRIO COMPETÊNCIA DOS MUNICÍPIOS PARA LEGISLAR SOBRE TEMPO MÁXIMO DE ESPERA DE CLIENTES EM FILAS DE BANCOS. REPERCUSSÃO GERAL. JURISPRUDÊNCIA PACÍFICA. RE 610.221 RG, (REL. MIN. ELLEN GRACIE, TEMA 272)

AGRAVO REGIMENTAL A QUE SE NEGA PROVIMENTO. ACÓRDÃO

Vistos, relatados e discutidos estes autos, acordam os Ministros do Supremo Tribunal Federal, em Segunda Turma, sob a Presidência da Ministra CÁRMEN LÚCIA, na conformidade da ata de julgamentos e das notas taquigráficas, por unanimidade, em negar provimento ao agravo regimental, nos termos do voto do Relator. Ausentes, justificadamente, os Senhores Ministros Celso de Mello e Gilmar Mendes.

Brasilia, 18 de dezembro de 2013

$$
\begin{aligned}
& \text { Ministro TEORI ZAVASCKI } \\
& \text { Relator } \\
& \text { Gupremo Sribunal Sederal } \\
& \text { Imetro Teor do Acordan - Pagina } 3 \text { de } 5
\end{aligned}
$$

$18 / 12 / 2013$

SEgunda TURMA

AG.REG. NO RECURSO EXTRAORDINÁRIO 559.650 MATO GROSSO

vото

O SENHOR Ministro TEORI ZAVASCKI (ReLATOR): 1. A irresignação não merece prosperar. O Plenário do Supremo Tribunal Federal, a analisar o RE 610.221 RG (Rel. Min. ELLEN GRACIE, DJe de 15/10/2010, Tema 272), reconheceu a repercussão geral do tema objeto do presente recurso extraordinário e ratificou sua jurisprudência, em ementa que ficou assim redigida:

DEFINIÇÃO DO TEMPO MÁXIMO DE ESPERA DE CLIENTES EM FILAS DE INSTITUIÇÓES BANCÁRIAS CLIENTES EM FILAS DE INSTITUIÇOES BANCARIAS COMPETENCA DO MUNICIPO PARA LEGISLAR ASSUNIO DE INTERSE LOCAL. RATIFICAÇ̃̃O DA JURISPRUDÊNCIA FIRMADA POR ESTA SUPREMA CORTE. EXISTÊNCIA DE REPERCUSSÃO GERAL 2010)

(RE 610.221 RG, Rel. Min. ELLEN GRACIE, Dje 20-08-

Nesse ponto a decisão agravada está em consonância com os precedentes desta Corte quanto à competência do município para legislar em assunto de interesse local. Confira-se o seguinte trecho da decisảo agravada:

“4. Tenho que a insurgência não merece acolhida. É que a jurisprudência do Supremo Tribunal Federal, que me parece juridicamente correta, é firme no sentido de reconhecer a competência dos municípios para legislar sobre questôe relacionadas à atividade bancária, notadamente quanto à segurança, ao conforto ou à prestação de serviços em prazo razoável.

5. Precedentes: AIs $429.070-\mathrm{AgR}$ e $574.296-\mathrm{AgR}$, sob a relatoria do ministro Gilmar Mendes; 491.420 -AgR, sob a

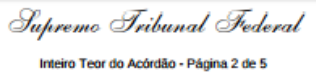

$18 / 12 / 2013$

Segunda Turma

AG.REG. NO RECURSO EXTRAORDINÁRIO 559.650 MATO GROSSO

RELATO

AGTE.(s)

ADv.(A/s)

AGDo.(A/s)

Proc.(A/S)(ES)

\section{:MIN. TEORI ZAVASCKI}

:BANCO DO BRASIL S/A

:JORGE ELIAS NEHME E OUTRO(A/s)

:MUNICIPIO DE ALTA FLORESTA

:PROCURADOR-GERAL DO MUNICIPIO DE ALTA

FLORESTA

RELATÓRIO

O SENHOR Ministro Teori ZAVAsCKi (Relator): Trata-se de agravo regimental de decisão que negou seguimento a recurso extraordinário sob o fundamento de que é pacífica a jurisprudência desta Corte no sentido de reconhecer a competência dos municípios para legislar sobre questōes relacionadas à atividade bancária, notadamente quanto à segurança, ao conforto ou à prestação de serviços em prazo razoável.

A recorrente alega, em suma, que "o recurso extraordinário foi interposto, também, pela violação aos princípios da proporcionalidade e razoabilidade, insertos no capítulo denominado de 'b) violação ao artigo $5^{\text {g, }}$ caput e inciso LIV da CF88'," (fls. 321).

É o relatório.

$$
\begin{aligned}
& \text { Suppremo OTribunal OFedeval } \\
& \text { Inteiro Teor do Acórdào - Página } 4 \text { de } 5
\end{aligned}
$$

RE 559650 AGR / MT

$$
\begin{aligned}
& \text { relatoria do ministro Cezar Peluso; e 347.717-AgR e 705.999, sob } \\
& \text { a relatoria do ministro Celso de Mello; bem como REs } 305.154 \text {, } \\
& \text { sob a relatoria da ministra Cármen Lúcia; 497.154, sob a } \\
& \text { relatoria do ministro Ricardo Lewandowski; e 561.699, sob a } \\
& \text { relatoria do ministro Eros Grau. " (fls.317) }
\end{aligned}
$$

O agravo regimental não traz qualquer subsídio apto a alterar esses fundamentos, razão pela qual deve ser mantido incólume o entendimento da decisão agravada.

2. Diante do exposto, nego provimento ao agravo regimental. É o voto.
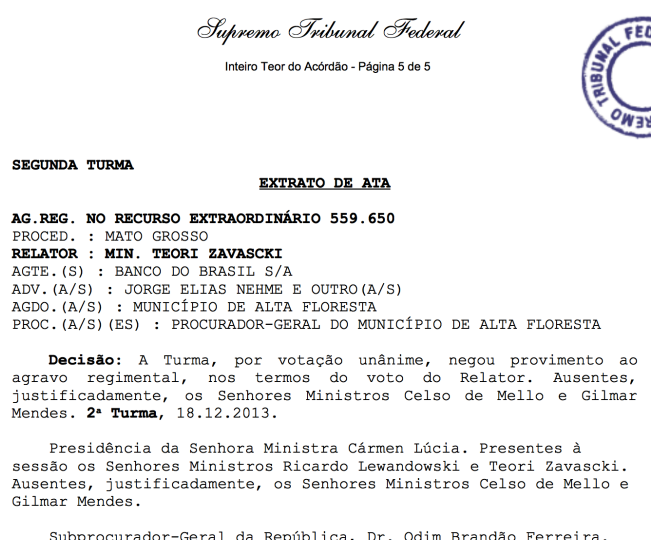

Subprocurador-Geral da República, Dr. Odim Brandão Ferreira.

Figura 1.1: Acórdão em seu inteiro teor 
Por este motivo, o STF disponibiliza em seu portal ${ }^{2}$, na área de Jurisprudência ${ }^{3}$, acesso a todos os acórdãos que formam a sua jurisprudência. Mas embora a Figura 1.1, demonstre um exemplo de acórdão em seu inteiro teor, a ferramenta de busca do STF realiza a pesquisa sobre versões mais resumidas dos acórdãos, como demonstrado na Figura 1.2 e por meio dela disponibiliza acesso aos acórdãos em seu inteiro teor. Este trabalho terá como foco trabalhar com os dados disponibilizados nas versões resumidas dos acórdãos, assim como é realizado no mecanismo de busca atual do STF.

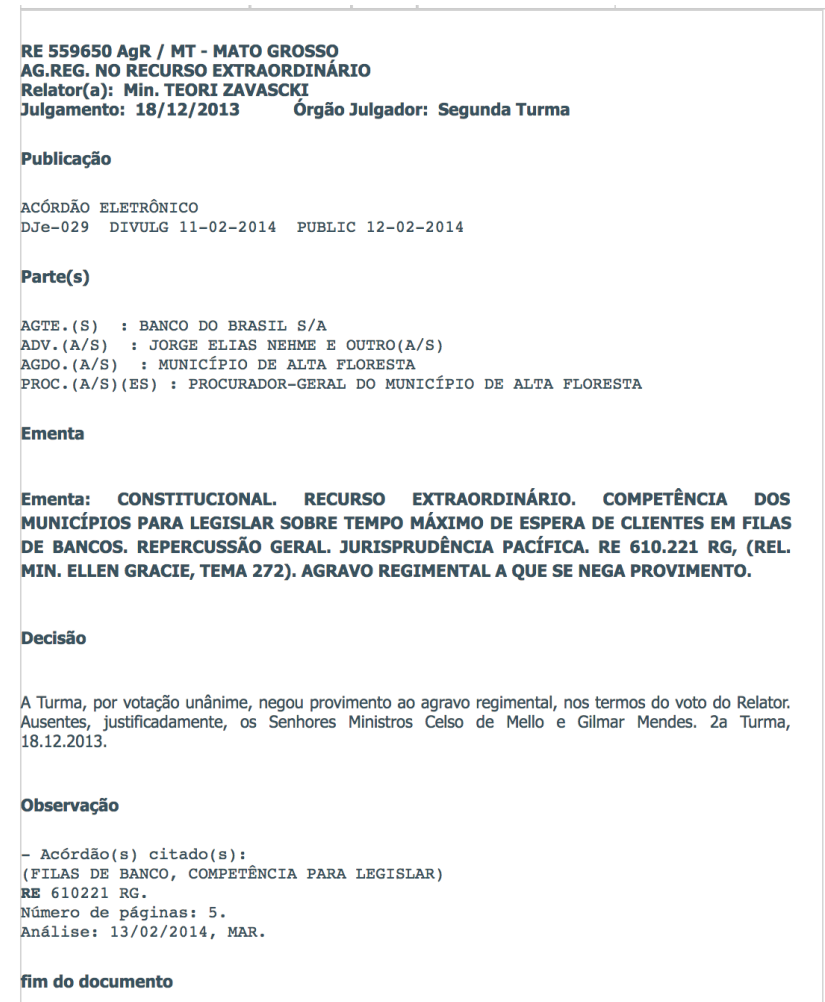

Figura 1.2: Mesmo acórdão da Figura 1.1 mas em uma versão resumida

Como pode-se observar na Figura 1.2, que é versão resumida de um acórdão, preserva muitas das informações originais contidas na versão inteiro teor e ainda disponibiliza informações adicionais, como:

- Acórdãos citados

- Acórdãos similares

- Legislações utilizadas

- Tags utilizadas para a indexação

Para consultar estes acórdãos, o STF por meio de uma ferramenta de busca, conforme demonstrado na Figura 1.3, permite a utilização de diversos critérios, como por exemplo:

- Número do acórdão

- Data do julgamento

- Órgão julgador

- Legislação

\footnotetext{
${ }^{2}$ http://stf.jus.br/

${ }^{3}$ http://stf.jus.br/portal/jurisprudencia/pesquisarJurisprudencia.asp
} 
Porém, mesmo com todos estes critérios a busca por meio desta ferramenta não é uma tarefa simples. Outro motivo é que na ferramenta do STF, mesmo disponibilizando um campo de "Pesquisa Livre"onde se pode utilizar linguagem natural, são levados em consideração somente os termos que foram informados na busca, ou seja uma busca puramente textual, e isso acaba por ainda demandar o trabalho de um especialista para separar o que é de relevância, mesmo porque a área jurídica sempre demandou conhecimento avançado. Serão dados mais exemplos da ineficiência da ferramenta do STF em uma seção futura.

Com base nessas dificuldades, o esforço deste trabalho, será o de melhorar o mecanismo de busca atual, demonstrando uma nova abordagem de consulta, por meio da construção e utilização de uma ontologia de domínio para a base de acórdãos do STF. E com isso, espera-se como resultado do trabalho, buscas mais dinâmicas e flexíveis por meio da web semântica.

\subsection{Motivação}

A base de dados do STF é composta por um grande volume de acórdãos, e além do que já existe, a cada dia mais, soma-se a esta base outros novos a medida que vão sendo julgados e relatados. $\mathrm{O}$ mecanismo do STF utiliza uma forma tradicional de busca baseado em formulários com inúmeros campos a serem preenchidos e selecionados Figura 1.3, se assemelhando a um questionário, no qual cada pergunta está relacionada a filtragem de certas informações em toda a base persistida em bancos de dados relacional.

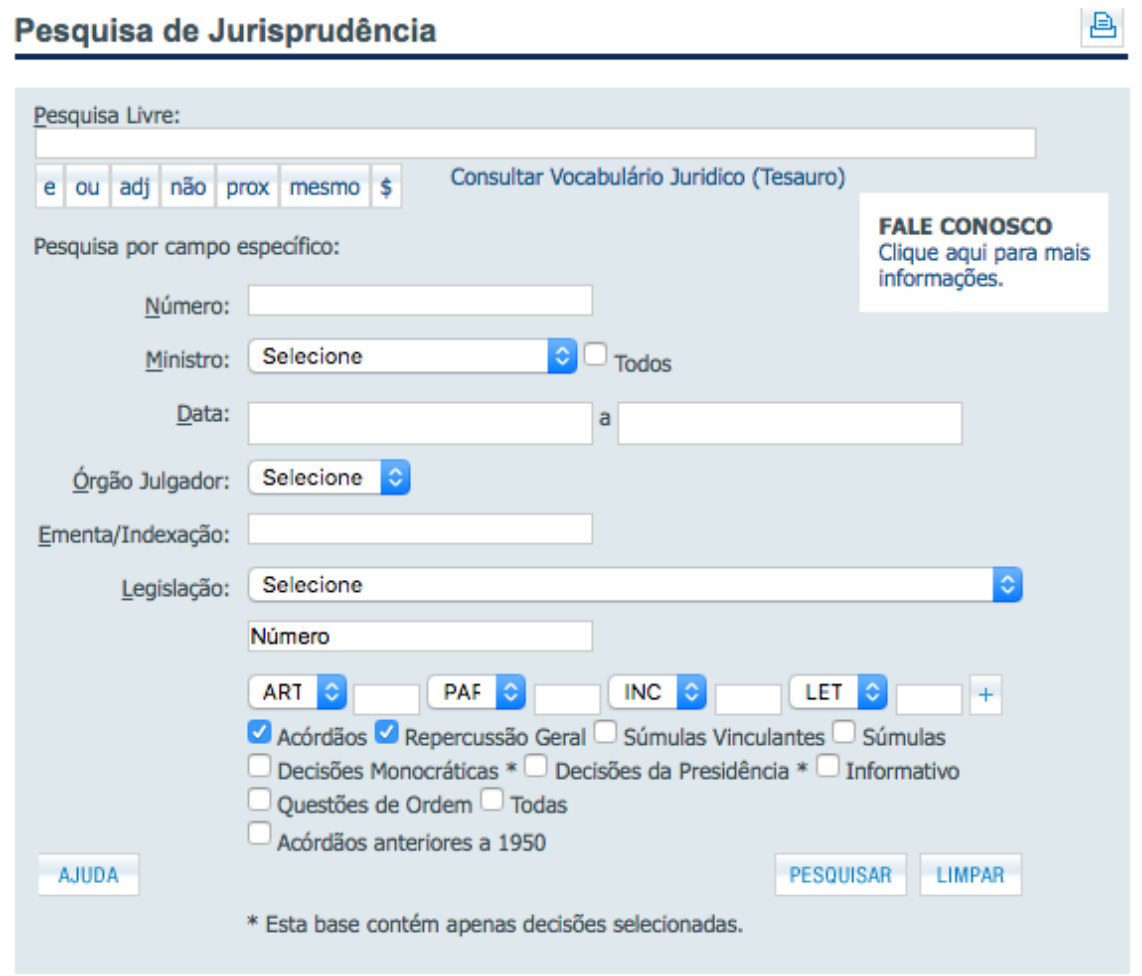

Figura 1.3: Interface atual de busca do STF

Do ponto de vista do usuário, esta abordagem é pouco intuitiva e imprecisa. Seria muito mais conveniente se o mecanismo permitisse a realização de buscas de interesse por meio de perguntas mais específicas, como por exemplo:

Quais ministros, enquanto relatores, são desafiados? 
Quais são os ministros mais desafiadores?

Como atualmente os acórdãos estão armazenados em base de dados relacionais, algumas informações requerem muitas tabelas para serem modeladas, e fazer consultas requer conhecimento sobre a estrutura das tabelas. Por isto, o desenvolvimento de um sistema de busca baseado em ontologias possibilitaria buscas mais dinâmicas, facilitando o processo de pesquisa até mesmo por pessoas que não possuem um conhecimento tão profundo na área jurídica.

\subsection{Objetivos}

- Construir uma ontologia de domínio para os acórdãos do STF.

- Implementar um sistema com interface web de pesquisa para os acórdãos

- Comparar o mecanismo de busca atual com o desenvolvido neste trabalho

\subsection{Contribuições}

Com este trabalho espera-se demonstrar os benefícios da estruturação dos acórdãos com a criação de uma ontologia de domínio sobre uma base de dados relacional.

\subsection{Organização do Trabalho}

No capítulo 2 são apresentados os principais conceitos concernentes a este trabalho. No capítulo 3 são apresentados trabalhos relacionados que serviram como base para este trabalho. No capítulo 4 é apresentada a metodologia seguida. No capítulo 5 é detalhada a construção da aplicação. No capítulo 6 são apresentados os resultados obtidos com a construção da aplicação e por fim no capítulo 7 é apresentada a conclusão e ideias para trabalhos futuros. 


\section{Capítulo 2}

\section{Conceitos}

Neste capítulo serão dadas algumas definições e conceitos fundamentais sobre ontologias, além de ferramentas, linguagens e o arcabouço para acesso a dados através de ontologias (Ontology Based Data Access, OBDA).

\subsection{Ontologias}

As ontologias são utilizadas hoje em diversas áreas do conhecimento, com o objetivo de organizar a informação. São encontradas na literatura diversas definições para ontologias, desde propostas para aplicação quanto para a construção de ontologias(metodologias, ferramentas e linguagens).

Uma das definições mais conhecidas para ontologias é apresentada por [Gruber, 1995] que diz que uma ontologia é uma "especificação explícita de uma conceitualização". O termo conceitualização corresponde a uma coleção de objetos, conceitos e outras entidades que se assume existirem em um domínio e os relacionamentos entre eles. Uma conceitualização é uma visão abstrata e simplificada do mundo que se deseja representar.

Esta interpretação por meio de conceitualização é discutida por [Giaretta e Guarino, 1995] quando, afirmam que a noção de conceitualização é um grupo de relações explícitas descrevendo um estado das coisas particular, enquanto que a noção que temos em mente é uma relação intensional, nomeando algo como uma rede conceitual a qual se superpõe a vários possíveis estados das coisas.

Com esta abordagem de aspecto intensional [Guarino, 1998], revê a definição de conceitualização a fim de obter uma interpretação mais clara. Ele se refere à ontologia como um artefato constituído por um vocabulário usado para descrever uma certa realidade e um conjunto de fatos explícitos e aceitos que dizem respeito ao sentido pretendido para as palavras do vocabulário. Este conjunto de fatos tem a forma da teoria da lógica de primeira ordem, onde as palavras do vocabulário aparecem como predicados unários ou binários. O vocabulário formado por predicados lógicos forma a rede conceitual que confere o caráter intensional às ontologias. A ontologia define as regras que regulam a combinação entre os termos e as relações.

Uma outra intepretação muito mais simples é dada por [Borst, 1997]. Para ele uma ontologia é uma especificação formal e explícita de uma conceitualização compartilhada. Nessa definição:

- Formal: significa legível para computadores.

- Especificação Explícita: diz respeito a conceitos, propriedades, relações, funções, restrições e axiomas explicitamente definidos.

- Compartilhado: significa conhecimento consensual.

- Conceitualização: diz respeito a um modelo abstrato de algum fenômeno do mundo real.

\subsection{Tipos de Ontologias}

As ontologias podem ser definidas de diversas formas: 
- Quanto à sua função [Mizoguchi et al., 1995]

- Quanto ao seu grau de formalismo [Uschold e Gruninger, 1996]

- Quanto à aplicação [Jasper e Uschold, 1999]

- Quanto à estrutura [Haav e Lubi, 2001]

- Quanto ao conteúdo [Haav e Lubi, 2001]

A ontologia utilizada neste trabalho é definida por sua função, e esta por sua vez, ainda é subdividida em três tipos, a saber:

- Ontologia de domínio: que fornece um vocabulário conceitual incluindo relacionamentos, atividades e regras sobre o domínio específico sendo modelado.

- Ontologia de tarefa: que fornece um sistema de vocabulário para descrever a resolução de problemas e a estrutura de todas as tarefas existentes no domínio.

- Ontologia geral: trata de termos de uso geral, como por exemplo: tempo, espaço, entre outros.

Dentre estes três tipos, a que será utilizada é uma ontologia de domínio. A escolha se deve ao fato dela ser a mais comum e geralmente utilizada para representar "micro-mundos". A ontologia de domínio descreve conceitos e vocabulários relacionados a domínios particulares, neste caso será utilizada para descrever o domínio jurídico dos acórdãos.

\subsection{Construção de Ontologias}

Primeiramente para a construção de uma ontologia de domínio, é necessário definir o seu domínio e escopo. Logo em seguida, ainda é necessário escolher uma metodologia, uma ferramenta e uma linguagem que serão utilizadas para definir a estrutura da ontologia.

Nem todas as ontologias possuem a mesma estrutura, mas todas possuem pelo menos um dos elementos básicos abaixo:

- Classes: normalmente organizadas em taxonomias, as classes representam conceitos dentro do domínio.

Exemplo: Pessoa.

- Relações: representam o tipo de interação entre os elementos do domínio (classes).

Exemplo: temRelator.

- Axiomas: são utilizados para modelar sentenças consideradas sempre verdadeiras. Exemplo: Voto $\sqsubseteq \exists$ temRelator.Pessoa.

- Instâncias: são utilizadas para representar elementos específicos, isto é, os próprios dados da ontologia.

\subsection{Metodologia para Construção de Ontologias}

As metodologias empregadas na construção de ontologias têm por objetivo organizar e definir um padrão para sua construção. O problema é que ainda não estão suficientemente maduras e não conseguem demonstrar um processo realmente estruturado a ponto de ser considerado um padrão de fato [Mendonça, 2015]. Por isso, [Guizzardi, 2000] sugere uma abordagem sistemática para a sua construção. Essa metodologia é composta por 6 fases. 
- Identificação de Propósito e Especificação de Requisitos

Tem como propósito identificar a competência da ontologia, que diz respeito à cobertura de questões que a ontologia deve responder. Assim, ao se estabelecer as questões de competência de uma ontologia, tem-se um meio eficaz de identificar o que é relevante ou não;

\section{- Captura da Ontologia}

Esta é considerada a fase mais importante, pois tem como objetivo identificar e organizar os conceitos e relações pertinentes. Conceitos devem ser definidos utilizando linguagem natural e exemplos. Deve-se ainda, construir taxonomias, de modo a organizar hierarquicamente as categorias e subcategorias. Axiomas devem ser providos para definir a semântica dos termos. Os axiomas especificam definições de termos na ontologia e restrições sobre sua interpretação;

- Formalização da Ontologia

Esta fase introduz a utilização de linguagens formais, pois o uso de linguagem natural muitas vezes introduz incertezas e ambiguidades, mas o uso de lingugagens formais, por meio de seus símbolos não ambíguos e formulações exatas, conduz a uma maior clareza e correção nas deduções;

\section{- Integração com Ontologias Existentes}

Na fase de captura e formalização, pode aparecer a necessidade de integrar a ontologia que se está criando com uma outra já existente, e isto deve ser incentivado pois é uma boa prática aproveitar conceitualizações previamente estabelecidas em outras ontologias, isso reduz o trabalho de ter que reinventar todos os conceitos novamente;

- Avaliação

A ontologia deve ser avaliada com base nas questões formais de competência, na sua especificação de requisitos ou no mundo real;

\section{- Documentação}

Todo o processo de construção da ontologia deve ser documentado, e esta etapa inclui os propósitos, requisitos e cenários de motivação, as descrições textuais da conceitualização, a ontologia formal e os critérios de projeto adotados;

A Figura 2.1 demonstra o diagrama de atividades que ilustra esta metodologia.

Da Figura 2.1, também é possível visualizar que na fase de "Avaliação e Documentação" pode ser detectado que a ontologia ainda não consegue dar respostas a todas as questões de competência. Neste caso, inicia-se o processo novamente a fim de se detectar, primeiramente o que faltou na "Identificação do Propósito e Especificação de Requisitos" e subsquentemente até que a ontologia esteja adequada para o domínio esperado.

\subsection{Ferramentas para Construção de Ontologias}

O processo de construção de uma ontologia é uma tarefa custosa e complexa, por isso existem algumas ferramentas e APIs que permitem desde a manipulação de ontologias, consultas e até integração com outras aplicações.

A ferramenta utilizada neste trabalho é o Protégé ${ }^{1}$ (versåo 5), veja a Figura 2.2. O Protégé foi criado no Centro de Pesquisa em Informática Biomédica da Universidade de Stanford, possui código aberto e por meio dele é possível criar e manipular ontologias. Outra característica muito interessante do Protégé é permitir a escalabilidade e extensibilidade através de uma arquitetura de plugins.

\footnotetext{
${ }^{1}$ http://protege.stanford.edu/about.php
} 


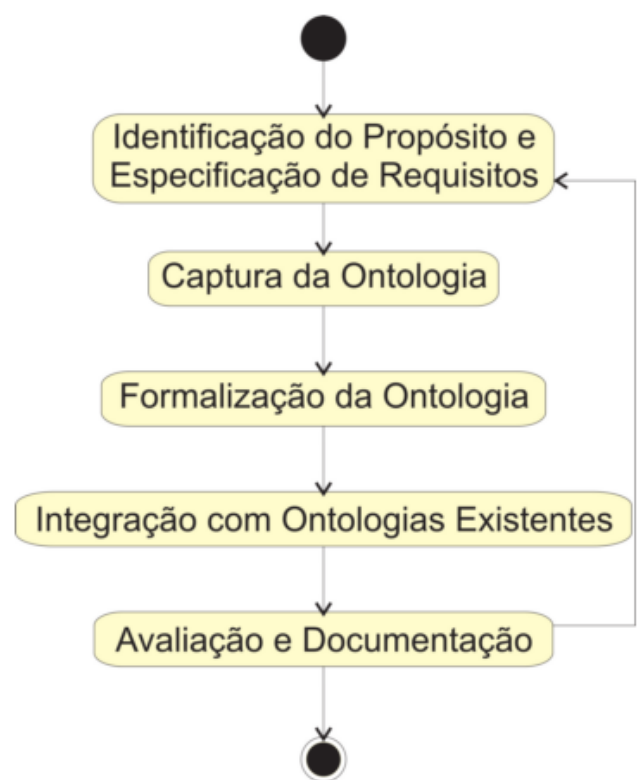

Figura 2.1: Diagrama de atividades da metologia proposta por [Guizzardi, 2000]. Fonte da imagem [Morais e Ambrósio, 2007].

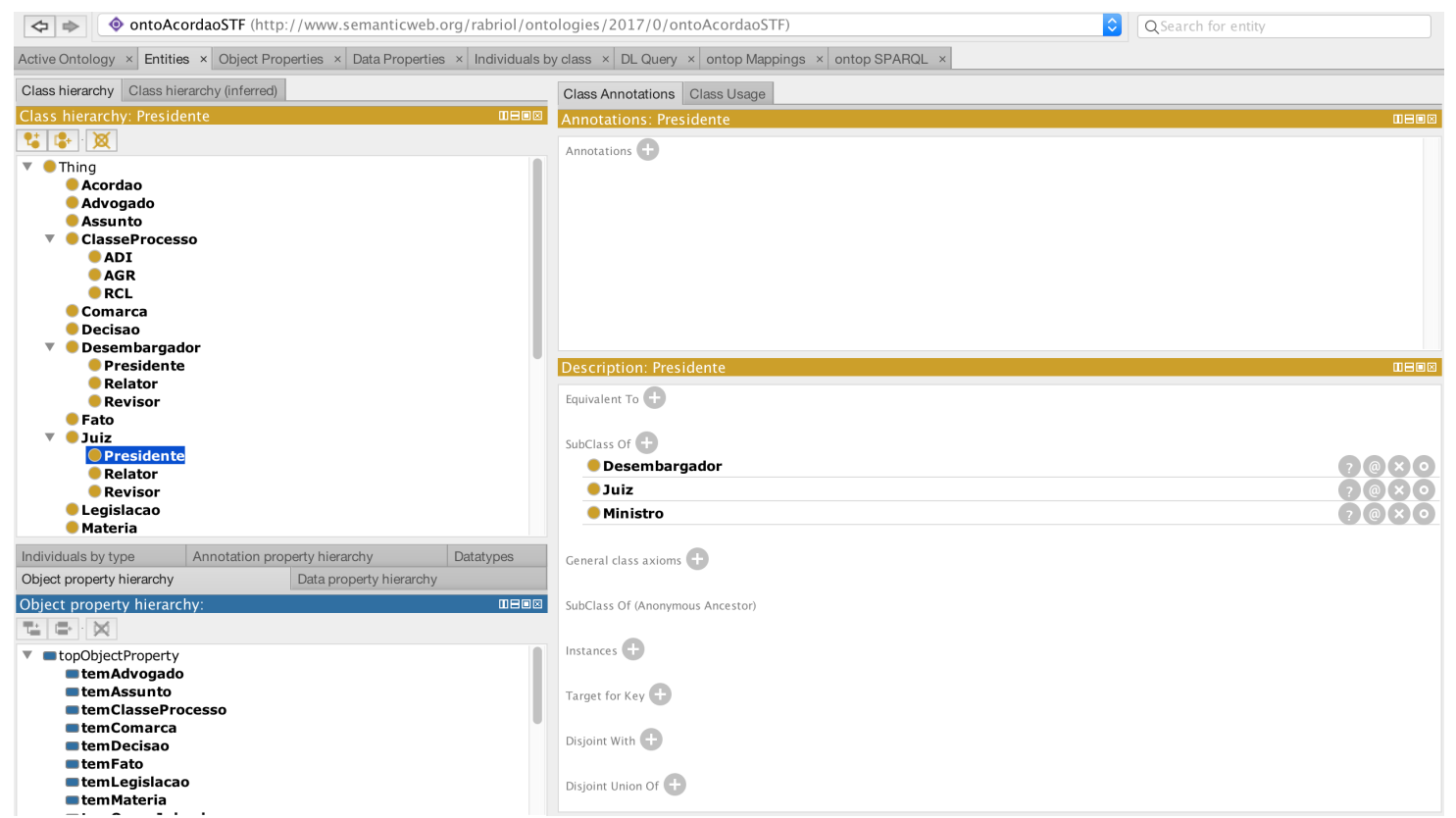

Figura 2.2: Protége

\subsection{Padrões para Representação de Ontologias}

Muitas linguagens utilizadas para representação de ontologias são baseadas na sintaxe XML (Extensible Markup Language), mas também existem outras como a Turtle ${ }^{2}$ e a $\mathrm{N}^{3}$.

\subsubsection{RDF}

Desenvolvido pelo W3C (World Wide Web Consortium), por meio da utilização de redes semânticas o RDF (Resource Description Framwork) tem como objetivo a representação do conhecimento, e como tal, permite a representação de conceitos, taxonomias de conceitos e relações binárias [Miller,

\footnotetext{
${ }^{2}$ https://www.w3.org/TR/turtle/

${ }^{3}$ https://www.w3.org/DesignIssues/Notation3.html
} 
1998].

A estrutura básica do RDF (Reource Description Framework) é um grafo dirigido e etiquetado, onde as arestas dão nome a ligação entre dois recursos, que são representados pelos nós do grafo. A formalização desse grafo é um conjunto de triplas, composto por sujeito, predicado e objeto.

A Figura 2.3 apresenta uma tripla em RDF.

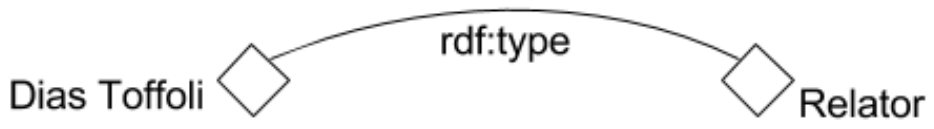

Figura 2.3: Exemplo de tripla em $R D F$

Fragmento de código em RDF:

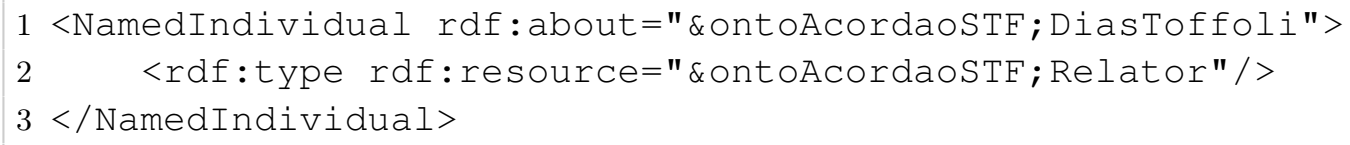

Os recursos no RDF fazem referência a qualquer elemento, abstrato ou não, eles podem também receber a denominação de entidades e devem sempre estar associados por um identificador, ou seja, uma URI que seja capaz de fornecer identificação única e global. A propriedade é um tipo especial de recurso dentro do RDF, que descreve relações. Isso facilita a utilização em um ambiente de conhecimento distribuído como a internet.

Apesar do RDF ter sido publicado pelo W3C em XML, o mesmo pode ser representado por meio de outras linguagens, como a Turtle e N3 mencionadas acima. Em comparação com o XML, elas não apresentam nenhuma diferença na capacidade de representação em termos de expressividade, mas facilitam a compreensão por humanos.

\subsubsection{RDFS}

O RDFS (Resource Description Framework Schema) foi criado com o intuito de expandir a expressividade semântica das descrições criadas em RDF, pois embora o RDF seja muito flexível e expressivo [Hebeler et al., 2011], por outro lado ele não consegue dar suporte para a especificação de significados semânticos.

O RDFS fornece mecanismos para descrever grupos de recursos relacionados e tipo de relação entre esses recursos. Uma classe em RDFS se assemelha a uma classe do paradigma de programação de orientação a objetos, pois é possível descrever hierarquias de especialização/generalização de classes e criar objetos como instâncias dessas classes.

Dentre as principais propriedades do RDFS, foram utilizadas na construção da ontologia as seguintes:

- rdfs:Class: é a classe de todas as classes;

- rdfs:Literal: é a classe de todos os literais (string, números, etc);

- rdfs:Property: é a classe de todas as propriedades;

Alguns dos termos presentes na codificação das relações semânticas em RDFS são:

- rdfs:type: que relaciona um recurso a uma classe, declarando-o como uma instância daquela classe; 
- rdfs:subClassOf: é quem relaciona uma classe com alguma de suas superclasses;

O RDFS ainda dá suporte para algumas restrições semânticas das propriedades, como:

- rdfs:domain: que especifica um domínio de uma dada propriedade, ditando que qualquer recurso que tem essa propriedade é uma instância das classes referenciadas nesse domínio;

- rdfs:range, que especifica a imagem da propriedade;

\subsubsection{OWL}

O OWL (Web Ontology Language) introduziu novas restrições na estrutura de representação do RDF, com o objetivo de tornar as inferências computacionais decidíveis. Dentre as várias características que a linguagem OWL apresenta, as mais relevantes para este trabalho são:

- Indivíduos

Os indivíduos representam o objeto no domínio de interesse. Como não utiliza o Unique Name Assumption, o OWL permite que dois nomes diferentes referenciem o mesmo indíviduo. Exemplo, Celso de Mello e Ministro Celso de Mello podem ser referências ao mesmo indíviduo. No OWL deve ser declarado explicitamente que os indíviduos são os mesmos, ou diferentes uns dos outros Horridge et al. [2009].

\section{- Propriedades}

As propriedades são relações binárias entre os indivíduos, esta relação pode ser entre uma instância de uma classe e um valor (DataType Property), ou entre dois indivíduos (Object Property) [Horridge et al., 2009]. Por exemplo, a propriedade tem Voto liga o indivíduo Acórdão ao indivíduo Voto, ou a propriedade temRelator pode ligar o indivíduo Voto ao indivíduo Relator Celso de Mello.

\subsubsection{OWL 2}

A nova versão da OWL, a OWL 2 [W3C, 2012], adicionou tanto poder quanto velocidade à linguagem, padronizando as características mais da primeira versão e introduz o conceito de perfis ou profiles. Os perfis são subconjuntos da linguagem que tem como intuito, melhorar a escalabilidade em aplicações específicas. Existem três diferentes perfis:

- $O W L 2 E L$

É mais adequado para aplicações onde ontologias muito grandes são necessárias, e onde o poder de expressividade pode ser trocado por garantias de performance. Permite a execução dos algoritmos de inferência com complexidade polinomial.

- $O W L 2 Q L$

É adequado para casos de ontologias relativamente leves e voltadas à organização de um grande número de indivíduos. Útil para casos onde é necessário acessar os dados diretamente através de consultas relacionais, como por exemplo em SQL. Permite a execução dos algoritmos de inferência com complexidade logarítimica.

- $O W L 2 R L$

É adequado para casos de ontologias relativamente leves e voltadas à organização de um grande número de indivíduos. Útil para casos onde é necessário acessar os dados diretamente na forma de construções RDF. Permite a execução dos algoritmos de inferência com complexidade polinomial.

Qualquer uma destas sublinguagens é também uma ontologia OWL 2 e pode ser interpretada usando a semântica direta ou via RDF. Cada uma define diferentes aspectos do poder de expressão da OWL com diferentes benefícios computacionais e de implementação. 


\subsection{SPARQL}

O SPARQL é uma linguagem de consulta que é capaz de recuperar e manipular informações armazenadas no formato RDF. Por ser uma linguagem orientada a dados, isso implica que não existe nenhum motor de inferência na própria linguagem.

As consultas no SPARQL são baseadas em triplas RDF, ou seja, compostas por sujeito, predicado e objeto.

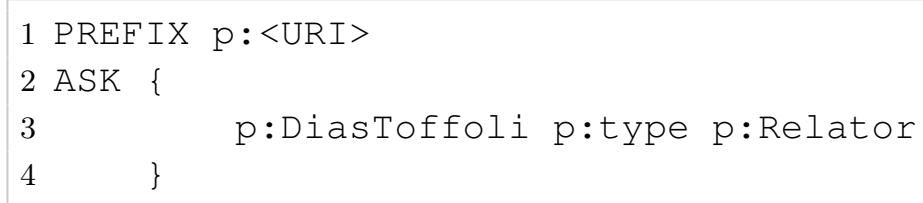

Na consulta acima $<$ URI $>$ é a URI, o identificador de recurso da ontologia. PREFIX é a palavra chave que declara p como um alias da URI. DiasTeofilo é o sujeito, type é o predicado e Relator é o objeto.

\section{Tipos de consultas}

Os tipos de consultas que o SPARQL provê de acordo com Seaborne et al. [2007], são:

- SELECT: é utilizado para extrair valores brutos de uma base RDF, os resultado são apresentados em uma tabela;

- CONSTRUCT: é utilizado para extrair informações de uma base RDF e transformar o resultado em um RDF válido;

- DESCRIBE: é utilizado para extrair um gráfico de uma base RDF;

- ASK: é utilizado para fornecer um resultado simples em formato booleano de uma base RDF;

\subsection{OBDA}

O OBDA (Ontology-based data access) [Bagosi et al., 2014] provê a especificação de um mecanismo de acesso a dados, por meio de uma camada semântica. Usualmente esta camada é expressa na forma de uma ontologia em RDF/RDFs ou OWL e o dado é armazenado em uma base de dados relacional. Os termos na camada semântica são mapeados para a camada de dados utilizando um mapeamento que associa cada elemento da camada semântica com uma consulta correspondente para a base de dados.

Após este mapeamento é gerado internamente um grafo virtual que permite consultas utilizando linguagens de consulta RDF como SPARQL.

Formalmente, um sistema OBDA é uma tripla [Bagosi et al., 2014] $\mathbf{O}=\langle\mathbf{T}, \mathbf{S}, \mathbf{M}>$, onde:

- T é a ontologia utilizada na camada semântica

- $\mathbf{S}$ é a base de dados relacional representando a fonte de dados

- M é o conjunto de asserções de mapeamentos, cada um na forma

$$
\Phi(\mathbf{x}) \leftarrow \Psi(\mathbf{x})
$$

onde

- $\Phi(\mathbf{x})$ é uma consulta sobre $\mathbf{S}$, e como resultado retorna tuplas $\mathbf{x}$ 
- $\Psi(\mathbf{x})$ é uma consulta sobre $\mathbf{T}$ onde as variáveis livres são $\mathbf{x}$

A principal função de um sistema OBDA é a execução de consultas. Uma descrição do processo de transformação de consultas (tipicamente do SPARQL para SQL) realizado por um sistema OBDA é mostrado na Figura 2.4 .

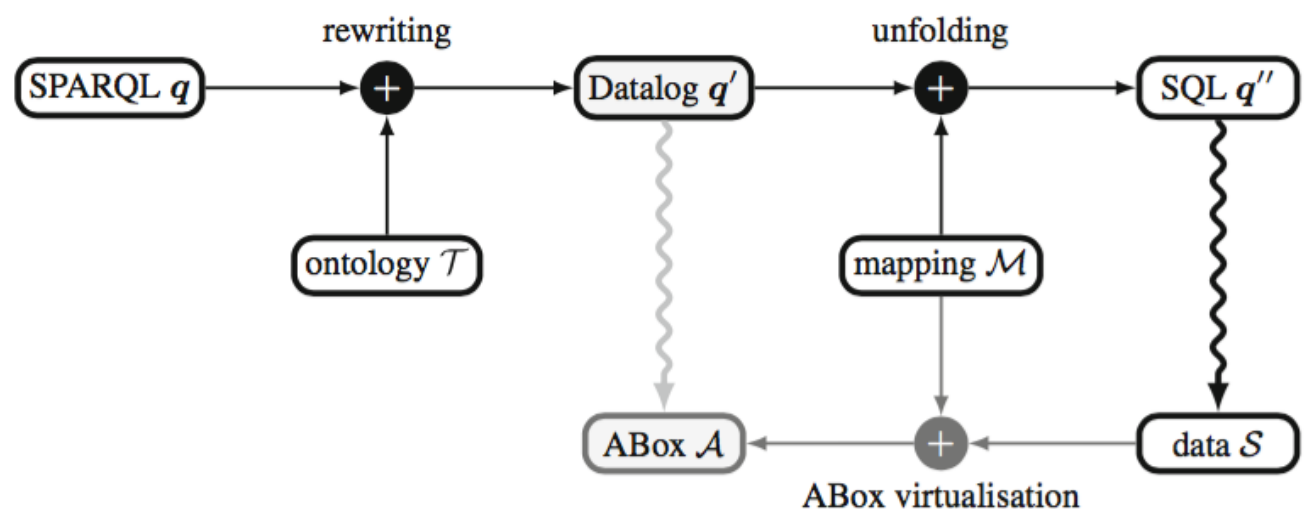

Figura 2.4: Processo de transformação de consulta em um sistema OBDA [Bagosi et al., 2014]

\subsubsection{O Framework Ontop}

O Ontop ${ }^{4}$ é um framework de código aberto para o OBDA, liberado sob a licença Apache e desenvolvido pela Free University of Bozen-Bolzano. Ele suporta todas as recomendações do W3C [Bagosi et al., 2014]: OWL, R2RML, SPARQL 1.0, SWRL e OWL2QL. Além disso os principais sistemas de banco de dados relacionais, tanto comerciais quanto livres, são suportados. Para cada componente do sistema OBDA, o Ontop suporta uma série de padrões:

- Mapeamento: O Ontop suporta duas linguagens de mapeamento: uma própria e nativa do próprio Ontop, a qual é de fácil aprendizado e utilização e a R2RML que é uma recomendação do W3C.

- Ontologia: O Ontop tem suporte completo ao OWL2 QL

- Base de Dados: O Ontop suporta todos os bancos de dados que implementam SQL99. Isto inclui a maioria dos bancos de dados relacionais como: PostgreSQL, MySQL, H2, DB2, Oracle.

- Consulta: O Ontop suporta todas as funcionalidades do SPARQL 1.0 e SPARQL OWL QL do SPARQL 1.1

O framework Ontop pode ser utilizado como:

- plugin para o Protégé 5 que provê uma interface gráfica para edição, mapeamento e execução de consultas SPARQL.

- biblioteca Java que implementa tanto a API OWL e API Sesame [Bagosi et al., 2014].

Neste trabalho iremos utilizar o plugin do Protégé para o framework Ontop e a biblioteca Java para desenvolvimento do mecanismo de consulta.

\footnotetext{
${ }^{4}$ http://ontop.inf.unibz.it/
} 


\section{Capítulo 3}

\section{Trabalhos Anteriores}

Neste capítulo serão apresentados trabalhos que em algum ponto estão relacionados com as necessidades do presente trabalho. São trabalhos que contribuiram para a obtenção dos acórdãos e reutilização de ontologia do domínio jurídico.

\subsection{Obtendo os Acórdãos do STF}

O acesso à base de dados do STF é fechado ao público, e por isso o desenvolvimento deste trabalho somente foi possível por meio da utilização dos dados obtidos no trabalho [Calò, 2014] "Extração e Análise de Informações Jurídicas Públicas", pois uma de suas contribuições, foi a criação de um algoritmo que utiliza a técnica de Web Scraping ${ }^{1}$ que consulta o portal do STF, realiza as consultas dos acórdãos e os extrai automáticamente armazendo-os no MongoDB ${ }^{2}$, que é um banco de dados do tipo não relacional, comumente conhecido pelo termo NoSQL ${ }^{3}$ e orientado a documentos. Os acórdãos obtidos compreenderam os períodos de publicação entre 2001 e 2012, totalizando cerca de 70.000 acórdãos.

A seguir é demonstrado um exemplo de um acórdão armazenado no MongoDB:

$$
\{
$$

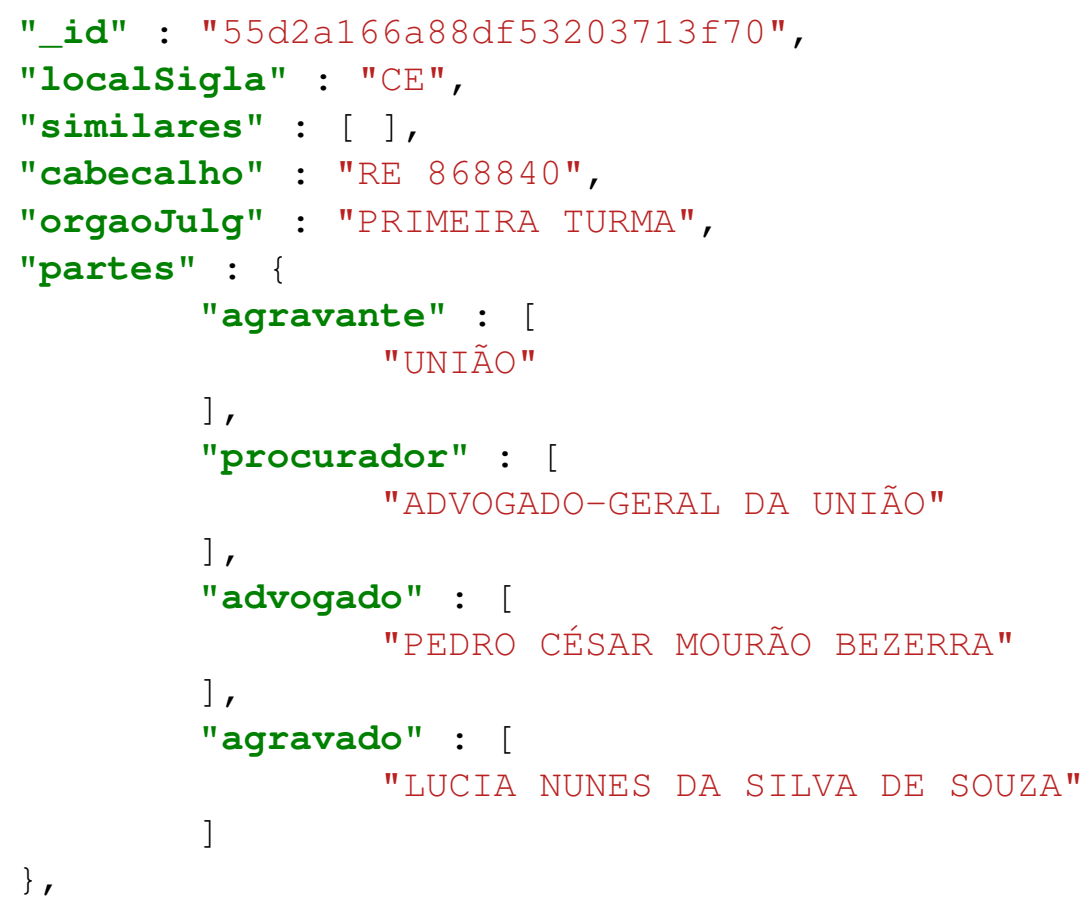

${ }^{3}$ https://www.mongodb.com/nosql-explained 


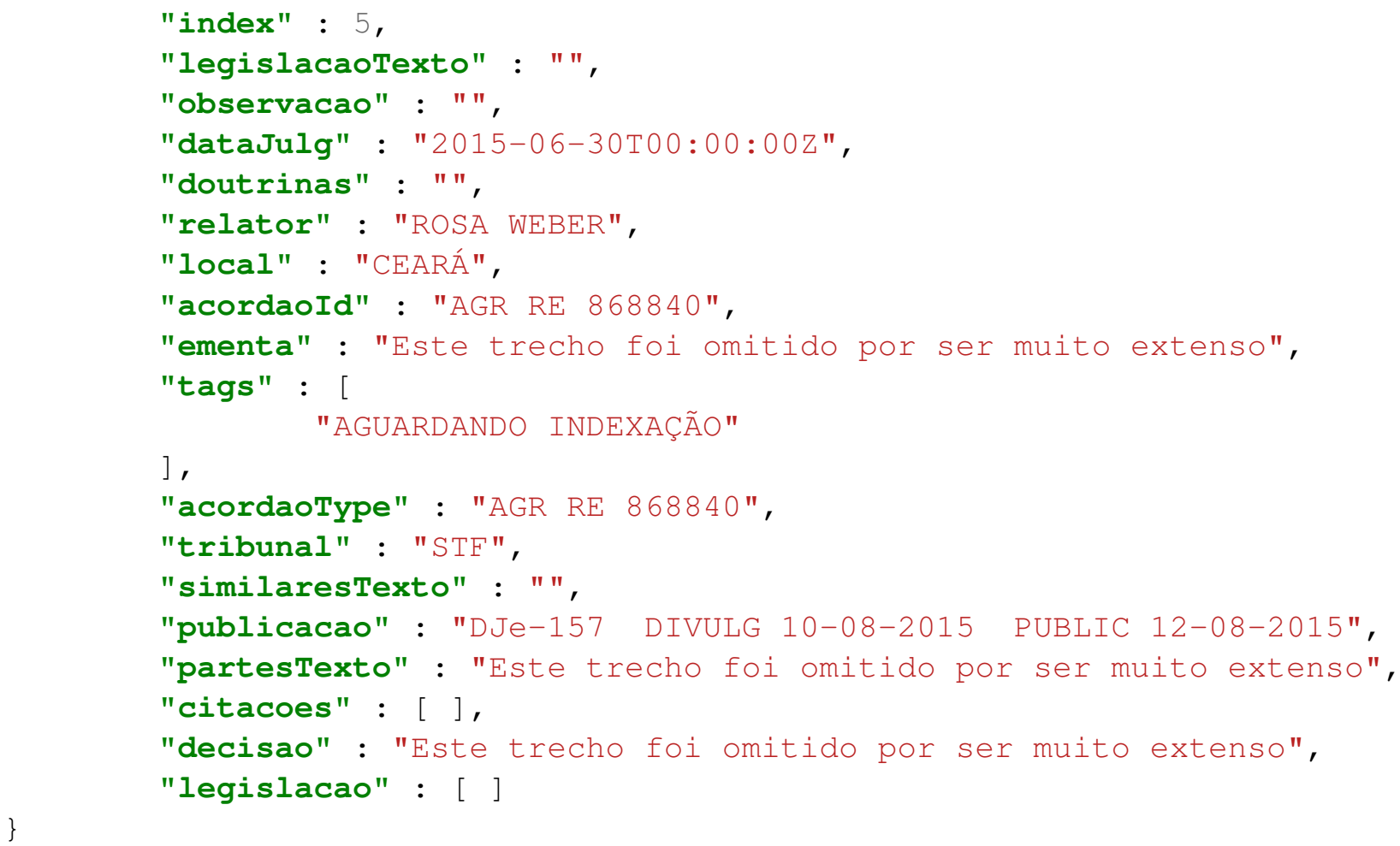

Como mencionado anteriormente, este trabalho utiliza a tecnologia OBDA para mapear os dados para a ontologia desenvolvida, e o OBDA, até o presente momento, provê suporte somente para banco de dados relacional, e devido a isto, foi necessário um trabalho de adaptação dos dados armazenados no MongoDB para o MySQL, que é um banco de dados relacional e consequentemente tem uma estrutura diferente do MongoDB. O trabalho de transferência resultou no modelo de dados apresentado na Figura 3.1.

Nesta fase de adaptação, pelo fato de alguns documentos de acórdãos possuírem uma formatação muito diferente do que a maioria dos outros, cerca de 10.000 documentos foram perdidos por não ser possível adaptá-los.

\subsection{Reutilização de uma Ontologia do Domínio Jurídico}

A fase de construção da ontologia, que será abordada na seção 4.2, teve início com a reutilização de uma ontologia pré-existente, fruto do trabalho de pesquisa dos autores [Bourguet e Costa, 2016]. Nele, os autores, após um extensivo trabalho de pesquisa, a fim de encontrar uma ontologia que servisse como modelo para todos os conceitos pertinentes a área jurídica, mais especificamente a jurisprudência do mesmo, modelaram uma ontologia denominada JurisJFES, mostrada na Figura 3.2. Esta ontologia tem um propósito muito mais abrangente e não se limita aos Acórdãos do STF, porém para as necessidades deste trabalho ela foi de grande utilidade. Além disso, como discutido pelos autores, a área jurídica carece de pesquisas voltadas à utilização de ontologias, por isso trabalhos demonstrando exemplos práticos de aplicações, muito contribuem para o avanço desta área.

Na Figura 3.2, as elipses representam as entidades e o losango representa as enumerações possíveis para as áreas do direito, tais como: direito civil, direito penal, direito administrativo, etc. As setas tracejadas representam uma relação de subtipo, onde é possível dizer, por exemplo, que todo relator também é um ministro. E enfim as setas não tracejadas representam relações de propriedade onde se diz, por exemplo, que um Acórdão tem Voto. 


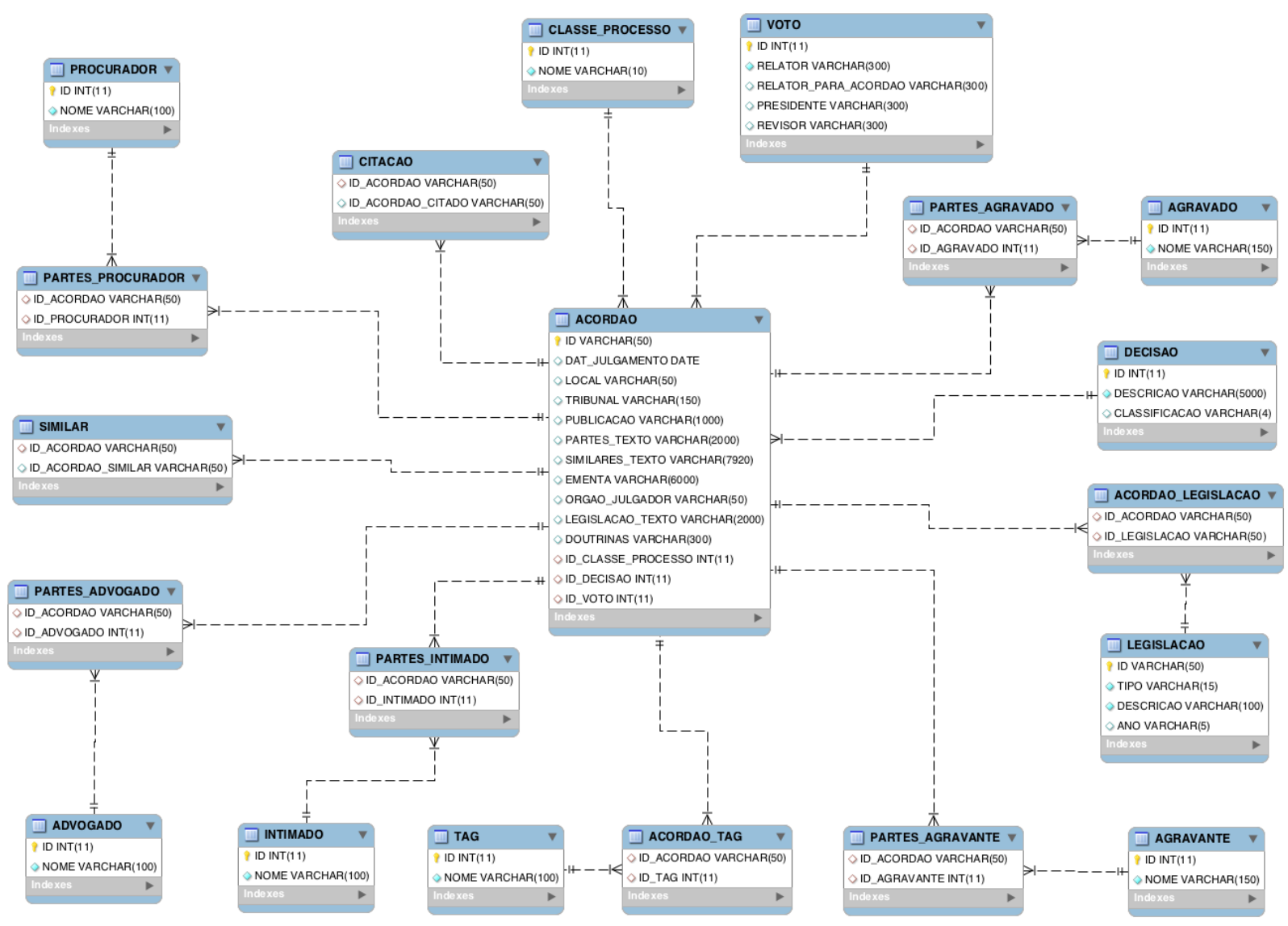

Figura 3.1: Modelo de dados da base relacional criada

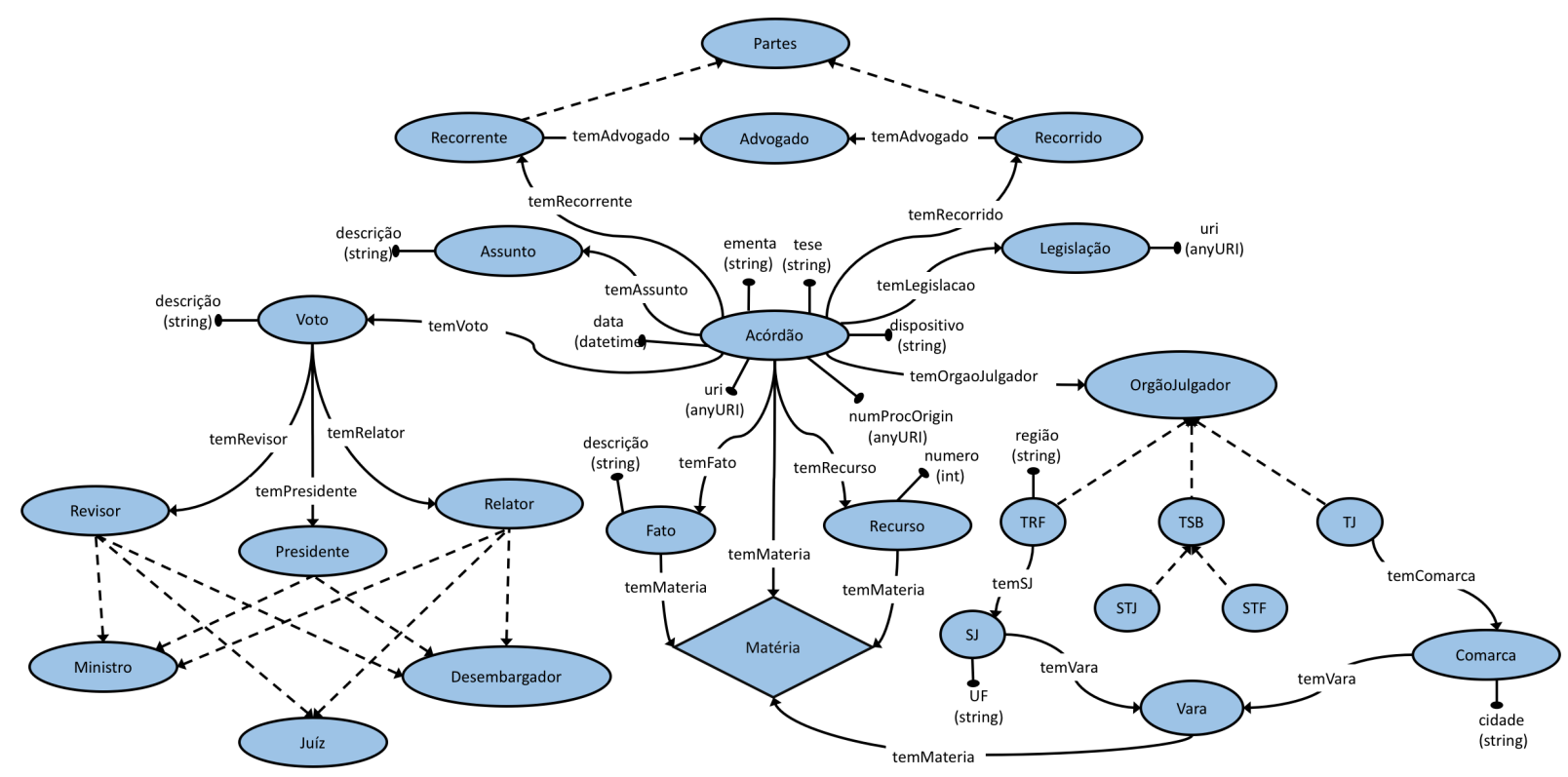

Figura 3.2: JurisJFES - ontologia proposta por [Bourguet e Costa, 2016] 


\section{Capítulo 4}

\section{Metodologia de Desenvolvimento}

Neste capítulo, seguindo a metodologia para construção de ontologias, conforme abordado na seção 2.4, será descrito detalhadamente o que foi feito em cada etapa do processo, desde da identificação das entidades até a validação da ontologia por meio de consultas em SPARQL.

\subsection{Identificação das Entidades e Relações da Ontologia}

Com o objetivo de identificar as entidades que deveriam pertencer ao domínio da ontologia, foi seguida a recomendação dada pelos autores [Grüninger e Fox, 1995]. Nesta recomendação, os autores instruem para que, acompanhado de um especialista de domínio, sejam levantadas questões de competência, cujas respostas a ontologia deve prover. Então juntamente com especialistas da área jurídica foram elaboradas, questões que auxiliaram na definição do escopo da ontologia, demostrado na Tabela 4.1:

\begin{tabular}{|c|c|}
\hline Numeração & Questão \\
\hline 1 & $\begin{array}{c}\text { Quais ministros do STF, enquanto relatores, dão provimento } \\
\text { para ações diretas de inconstitucionalidade? }\end{array}$ \\
\hline 2 & Quais ministros são desafiados? \\
\hline 3 & Quais ministros são os desafiadores? \\
\hline
\end{tabular}

Tabela 4.1: Questões de competência

Mesmo após o levantamento das questões de competência ainda foram necessários mais alguns passos, estes agora, para entender como extrair das questões, as entidades e suas relações. Desta forma, com a ajuda dos especialistas, as 3 questões de competência podem ser entendidas da seguinte forma:

\section{Questão 1}

Quais ministros do STF, enquanto relatores, dão provimento para ações diretas de inconstitucionalidade?

O primeiro trecho "Quais ministros do $S T F$ ", significa que Ministro é uma entidade do orgão $\mathrm{STF}$, já no segundo trecho "enquanto relatores" significa que o mesmo Ministro pode também exercer o papel de Relator, ou seja, há uma relação onde um Relator é um subtipo de um Ministro. No terceiro trecho é dito "dão provimento", o ato de dar provimento se resume em olhar para a decisão do acórdão e identificar se a decisão dos ministros foi favorável ou não ao recurso do réu ou à petição do autor. Ou seja, aqui pode-se extrair que um Acórdão possui uma Decisão e uma Decisão por sua vez possui uma Classificação que se desdobra em favorável ou não favoráel. Por fim o último trecho "para ações diretas de inconstitucionalidade", conforme abordado na introdução 
deste trabalho, significa um tipo de classe de processo que um acórdão pode ter, em outras palavras Ação Direta de Inconstitucionalidade (ADI) é a ação que tem por finalidade declarar que uma lei ou parte dela é inconstitucional, ou seja, contraria a Constituição Federal.

\section{Questão 2}

Quais ministros são desafiados

O primeiro trecho "Quais ministros" indica mais uma vez o papel de Ministro, e por último "são desafiados" indica que um ministro pode ser desafiado. Este desafio ocorre quando o Ministro, que a princípio estava responsável por ser o Relator do processo, têm o seu voto vencido por outro ministro que foi o primeiro a proferir o voto vencedor. Este ministro então assume o papel de Relator para Acórdão. Aqui a nova entidade encontrada é de Relator para Acórdão que também é um subtipo de Ministro.

\section{Questão 3}

\section{Quais ministros são os desafiadores}

A Questão 3 é muito semelhante a Questão 2 onde o foco é identificar os Ministros desafiados, e uma vez identificados também é possível identificar quem são os ministros desafiadores, pois em ambas questões aparece tanto o papel de Relator quanto de Relator para Acórdão.

Após a explicação e entendimento destes conceitos pertinentes as questões de competência, foram identificadas algumas entidades e suas relações, conforme descrito na Tabela 4.2:

\begin{tabular}{|c|c|c|}
\hline Entitade 1 & Relação & Entitade 2 \\
\hline Relator & é um & Ministro \\
\hline Relator para Acórdão & é um & Ministro \\
\hline Voto & temRelator & Relator \\
\hline Voto & temRelatorParaAcordao & Relator para Acórdão \\
\hline Acórdão & temVoto & Voto \\
\hline Acórdão & temDecisao & Decisão \\
\hline Acórdão & temClasseProcesso & Classe de Processo \\
\hline Decisão & temClassificacao & Classificação \\
\hline Relator & desafiado por & Relator para Acórdão \\
\hline
\end{tabular}

Tabela 4.2: Entidades e suas relações

\subsubsection{Treinamento e classificação das Decisões dos Acórdãos}

Uma das questões de competência que demandou um trabalho adicional, foi:

- Quais ministros do STF, enquanto relatores, dão provimento, para ações diretas de inconstitucionalidade?

Para saber se uma decisão é favorável ou não, foi preciso extrair isso do próprio texto das decisões, pois conforme podemos ver no exemplo da Figura 4.1, uma decisão de um Acórdão não deixa explícita essa informação.

\section{Decisão}

A Turma, por unanimidade, negou provimento ao agravo, com aplicação de multa, nos termos do voto do Relator. Primeira Turma, Sessão Virtual de $1^{0}$ a 8.9.2017.

Figura 4.1: Exemplo de uma decisão de um Acórdão 
Para extrair este tipo de informação, foi utilizada uma técnica de Machine Learning (Aprendizagem de Máquina), chamada Naive Bayes. Conforme demonstrado por [Rish, 2001], a técnica Naive Bayes possui um alto desempenho na classificação automática de textos e seu uso compreende duas fases, sendo a primeira de aprendizado e por último a de classificação.

$\mathrm{Na}$ fase de aprendizado foram separadas e classificadas manualmente, 2000 decisões. As 2000 decisões, de maneira resumida, apresentam os seguintes tipos de decisão:

\begin{tabular}{|c|c|}
\hline Trecho da decisão & Classificação \\
\hline deu provimento ao agravo regimental... & positivo \\
\hline deu provimento parcial ao agravo regimental... & positivo \\
\hline julgou procedente a ação direta... & positivo \\
\hline deu provimento ao recurso extraordinário... & positivo \\
\hline julgou improcedente a ação direta... & negativo \\
\hline rejeitou os embargos de declaração... & negativo \\
\hline negou provimento ao agravo regimental... & negativo \\
\hline negou provimento ao recurso extraordinário... & negativo \\
\hline
\end{tabular}

Tabela 4.3: Tipos de decisões contidadas nos Acórdãos

Uma classificação do tipo positivo corresponde a uma decisão favorável e negativo a uma decisão não favorável.

As decisões classificadas manualmente, serviram como insumo para a fase de classificação automática, e como resultado final foram obtidas aproximadamente 20.000 classificações para as decisões. Não foi possível obter mais decisões classificadas, pois dos 60.000 acórdãos somente 20.000 aproximadamente possuiam o campo decisão preenchido.

No processo de classificação das decisões não houve uma preocupação quanto as métricas dos resultados obtidos. Poderiam ter sido extraídos métricas como precisão, cobertura e medida F. A própria classificação de uma decisão da maneira que foi realizada não é tão precisa, pois uma decisão pode ser parcial, neste caso, quando não há unânimidade entre os ministros. Porém como isso iria muito além do escopo deste trabalho, foi tomada a decisão de classificar os acórdãos com um valor aproximado.

\subsection{Construção da ontologia}

Algumas das entidades que foram extraídas das questões de competência, foram encontradas na JurisJFES, conforme pode-se verificar na Figura 3.2, porém ainda não eram suficientes para cobrir todas as entidades encontradas, e por isso outras tiverem de ser acrescentadas, resultando então na ontologia da Figura 4.2.

As entidades adicionadas, dizem respeito a Classe Processo, Decisão e um novo papel para os ministros que é o de Relator para Acórdão.

Os acórdãos podem ter diferentes tipos de Classe de Processo, mas como abordado na Questão 1 da seção 4.1, este trabalho irá utilizar somente a classe de processo ADI. Todo Acórdão também possui uma Decisão, que por sua vez contêm duas propriedades de dados, sendo uma de descrição, onde está presente o texto da decisão, conforme relatado pelo Ministro Relator e uma outra de "classificação", esta do tipo binária e que pode assumir os valores "positivo" ou negativo como já abordado na seção 4.1.1.

A ontologia JurisJFSP se encontra disponível no endereço eletrônico https://github.com/rabriol/ ontologia_jurisjsp/blob/master/jurisjsp.png.

Após isto então, utilizou-se a ferramenta Protége e para a construção seguiu-se 4 etapas que serão descritas a seguir. 


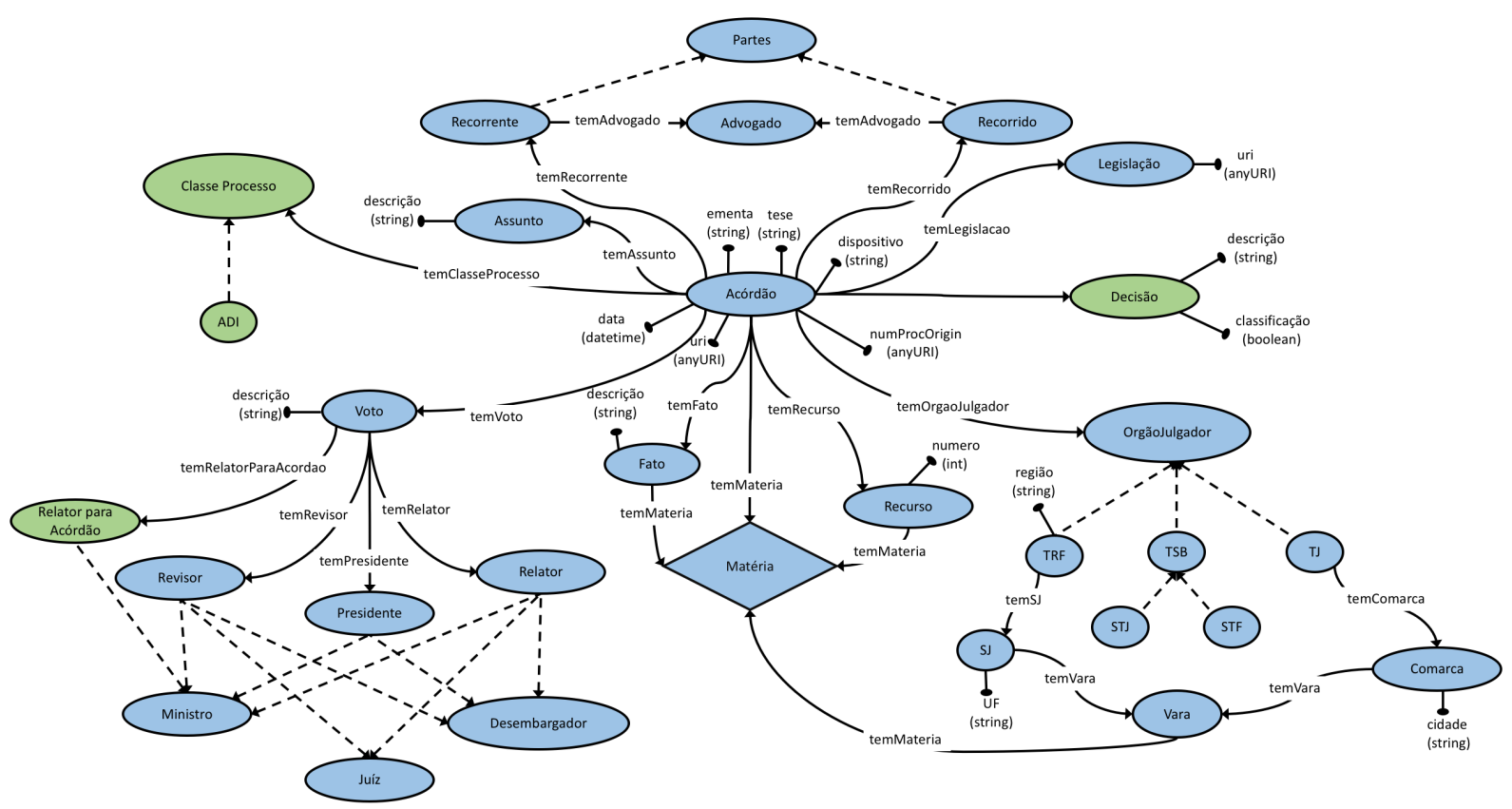

Figura 4.2: JurisJFSP - ontologia adaptada para este trabalho

\subsubsection{Formalização da Ontologia}

A primeira parte é a formalização em OWL da ontologia JurisJFSP. Na Figura 4.3, é apresentada a hierarquia de classes mencionadas. Nesta figura existe a relação "SubClassOf", que é representada pelas setas, e é utilizada fazendo a ligação entre classes, assim cada filho de uma classe é uma subclasse, e está relacionando uma classe pai através da relação "SubClassOf". Tomando como exemplo a classe Ministro, podemos dizer que tanto um Relator, Relator para Acórdão, Revisor e Presidente também são ministros.

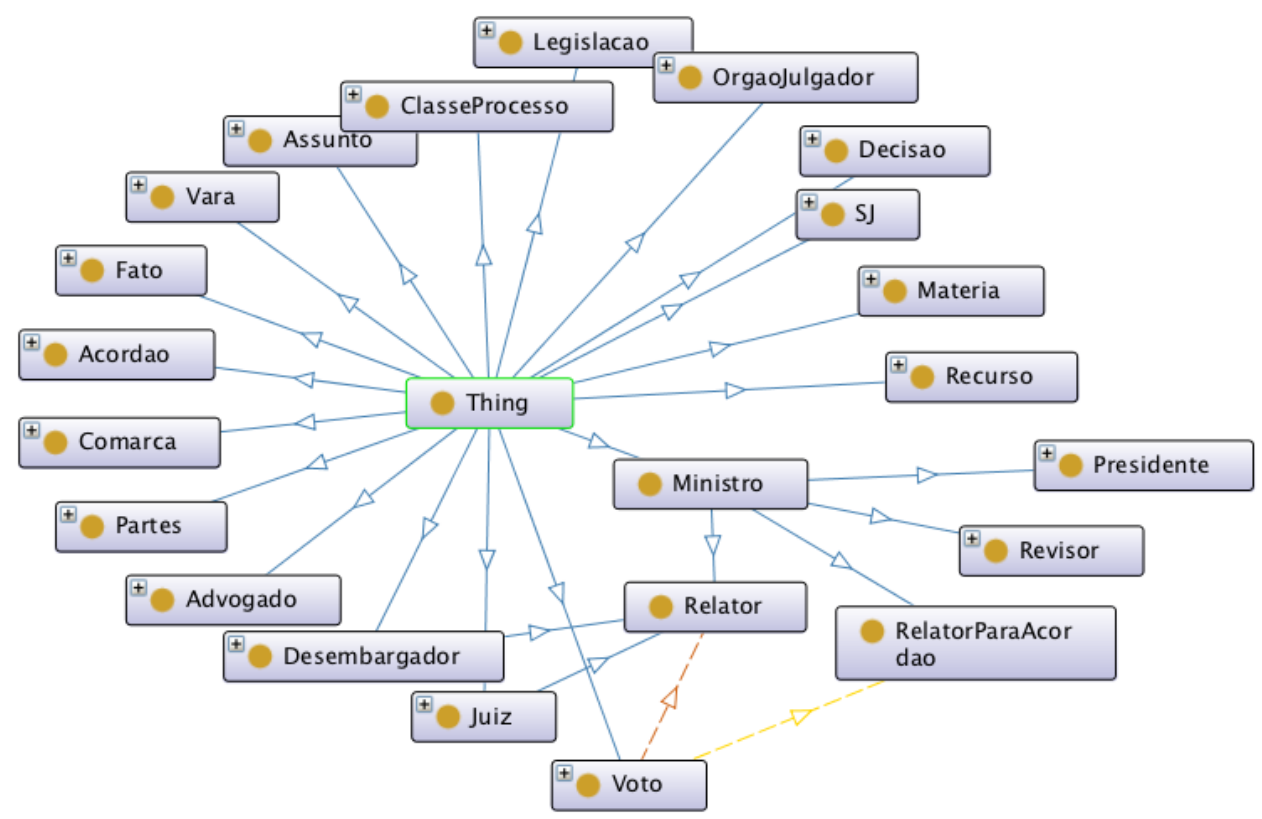

Figura 4.3: Hierarquia de classes da ontologia no domínio dos acórdãos do STF

Na Figura 4.3 as duas setas tracejadas significam respectivamente "propriedades de objetos" onde é dito que um Voto $\sqsubseteq \exists$ temRelator.Pessoa e Voto $\sqsubseteq \exists$ temRelatorParaAcordao.Pessoa. As 
demais setas descrevem uma relação de subtipo, por exemplo a classe Relator é um subtipo da classe Ministro.

\subsubsection{Criação das Propriedades de Objeto}

A segunda parte é a criação das propriedades de objeto e os tipos de dados da ontologia JurisJFSP, como por exemplo:

1. temVoto

2. temDecisao

3. temClasseProcesso
4. temRelator

5. temRelatorParaAcordao

6. temClassificacao

Para a criação de propriedades de objeto o Protégé possui a aba "Object Properties", que permite que sejam criadas relações entre as entidades, como por exemplo a relação "temVoto"que liga a entidade Acórdão com o Voto. A figura 4.4 demonstra as propriedades criadas para a ontologia.

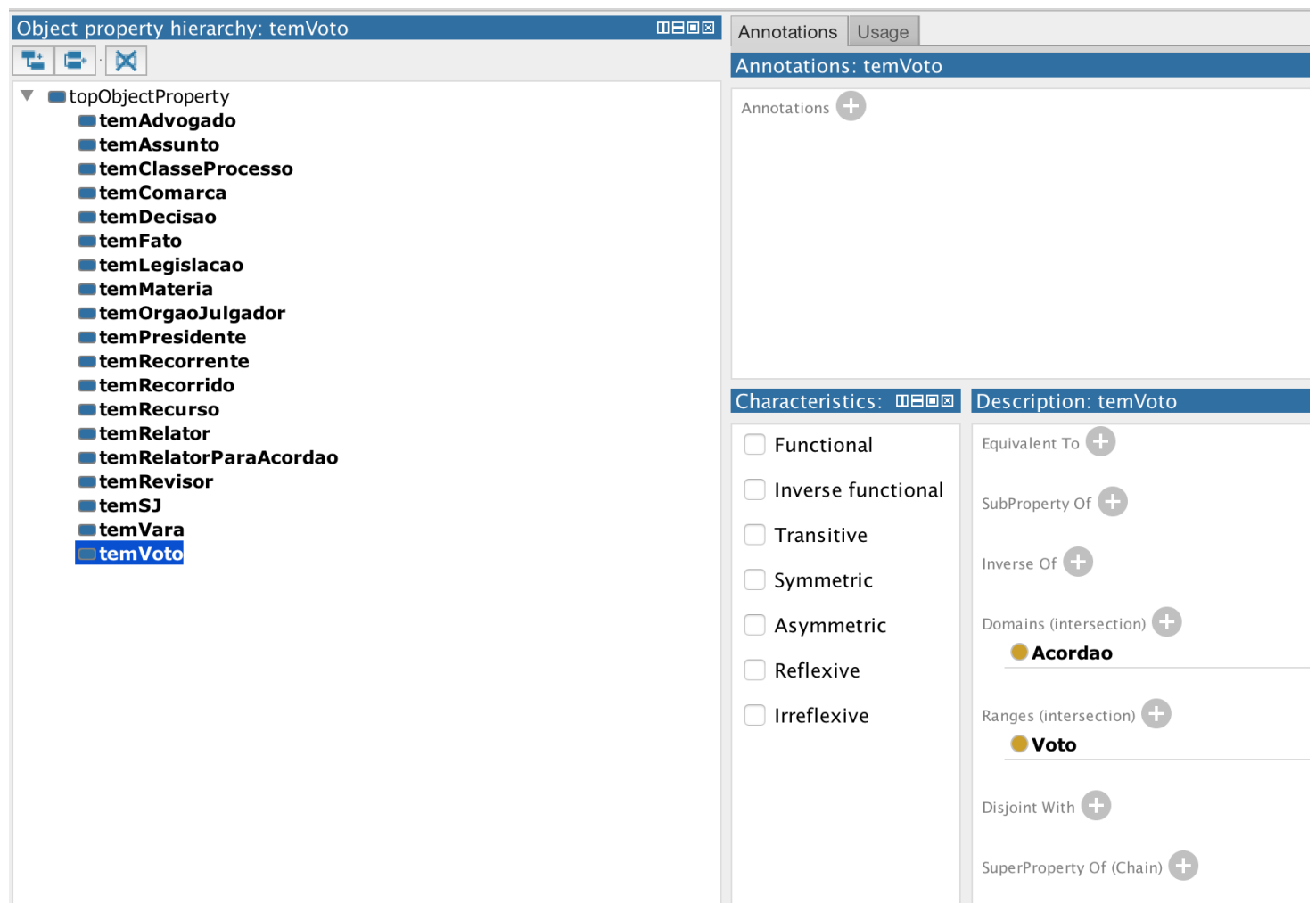

Figura 4.4: Hierarquia de classes da ontologia no domínio dos acórdãos do STF

\subsubsection{Criação das Propriedades de Dados}

A terceira parte é a criação de propriedades de dados, o Protégé possui a aba "Data Properties". Nesta aba é possível criar as relações que fazem a ligação entre uma entidade e um literal, ou tipo de dados. Como exemplo, a Figura 4.5 demonstra a propriedade decrição, que tem como tipo de dado string e pode ser utilizado dentro do domínio das classes Decisão, Fato, Assunto e Voto.

\subsubsection{Mapeamento com OntoP}

A quarta e última parte foi a criação dos mapeamentos do banco relacional para as classes da ontologia, e para isto foi utilizado o plugin OntoP do Protégé. O plugin OntoP do Protégé possui 3 abas, a primeira é a "Datasource Manager", Figura 4.6. Por meio desta aba é feita a configuração 


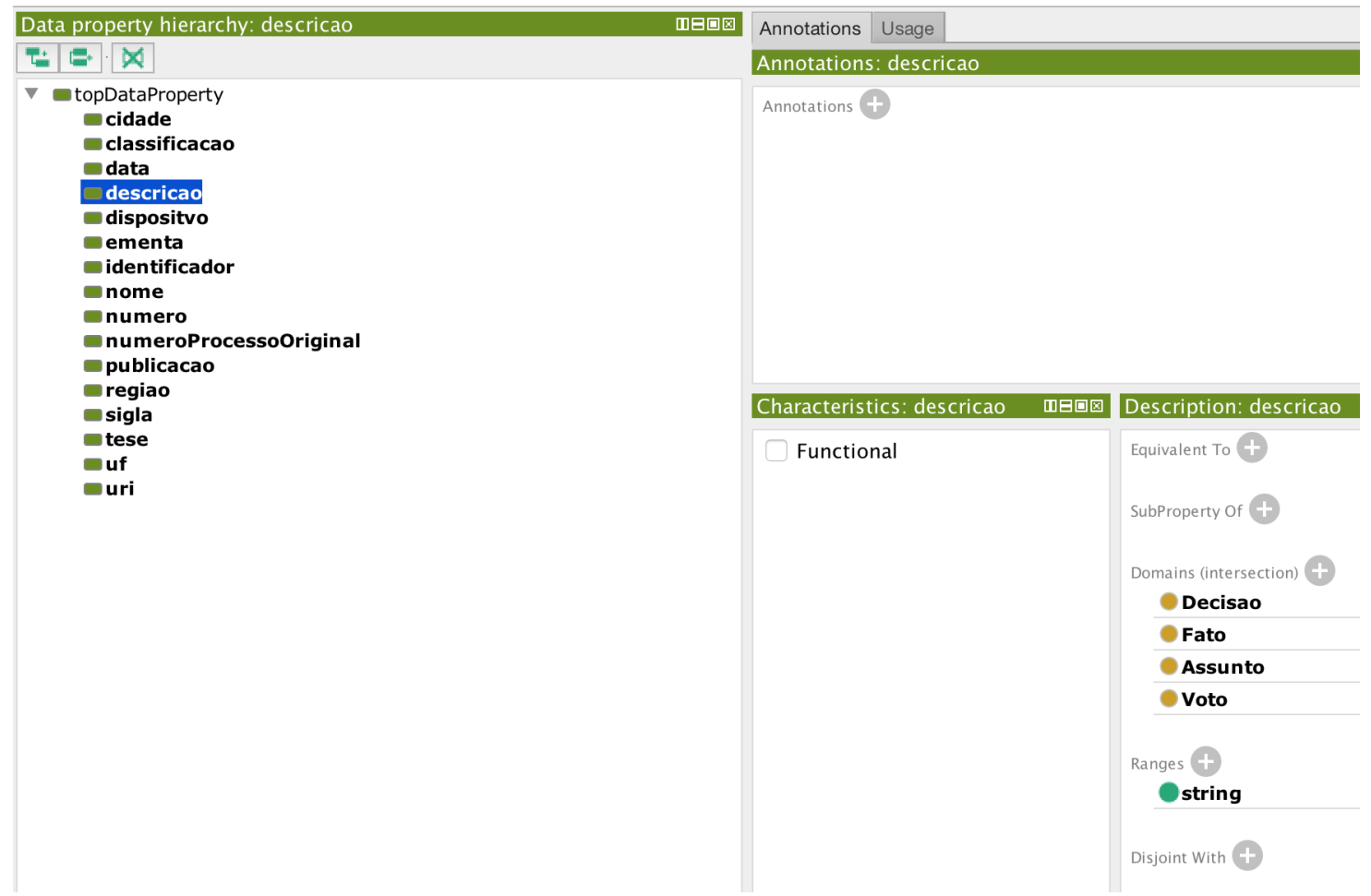

Figura 4.5: Aba de definição de tipo de dado do Protégé

da fonte de dados, de onde se estabelece uma conexão com o banco de dados relacional, lugar este, onde os acórdãos estão armazenados. As informações necessárias para conexão são:

- Datasource Name: Nome dado à conexão que será configurada.

- Connection URL: Endereço do local onde o banco de dados relacional esta instalado.

- Database Username: Todo banco de dados possui a configuração de uma usuário. Isso se dá por motivos de segurança.

- Database password: Em algumas conexões além do usuário também é necessário o password.

- Driver Class: O Driver deve ser selecionado de acordo com o banco de dados relacional que se deseja acessar. Como os acórdãos utilizados no presente trabalho estão no banco de dados MySQL, entáo deve-se usar o Driver "com.mysql.jdbc.Driver".

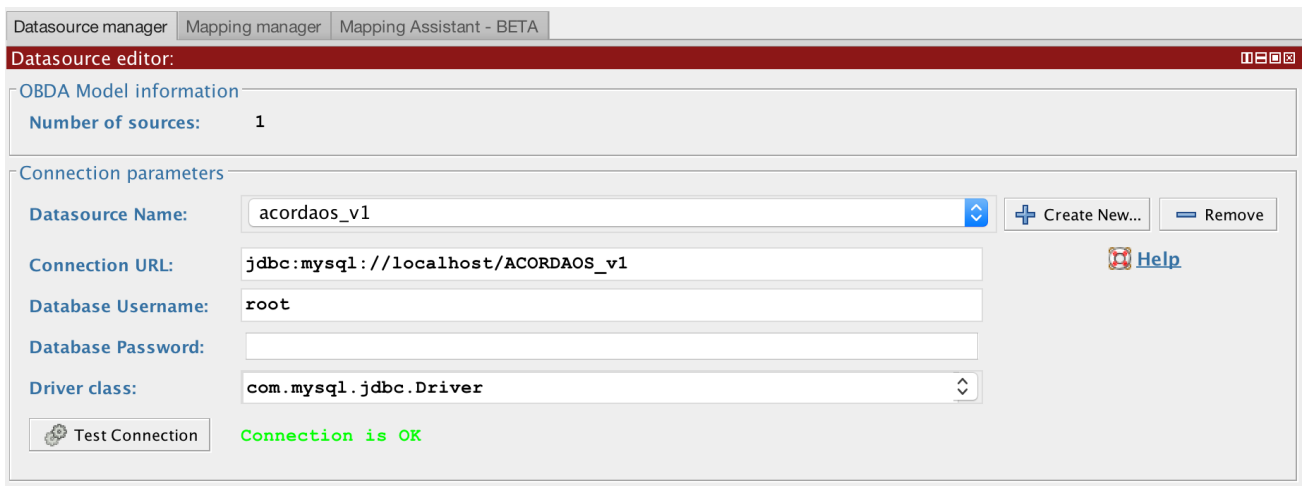

Figura 4.6: Aba do OntoP para criação do datasource

A segunda aba é a "Mapping Manager", ilustrada na Figura 4.7, nesta aba é possível realizar a criação, edição e remoção dos mapeamentos. Porém está aba é mais utilizada para visualizar e 
editar os mapemantos ja realizados, uma vez que existe outra aba, mais adequada para a criação dos mapeamentos.

No exemplo da Figura 4.7, é criado o mapeamento que define o atributo ID, atributo este recuperado da tabela ACORDAO do banco dados relacional, como sendo um tipo de Acórdão. Esta configuração é identificada pelo trecho :(ID) a:Acordao e é equivalente ao fragmento em RDF:
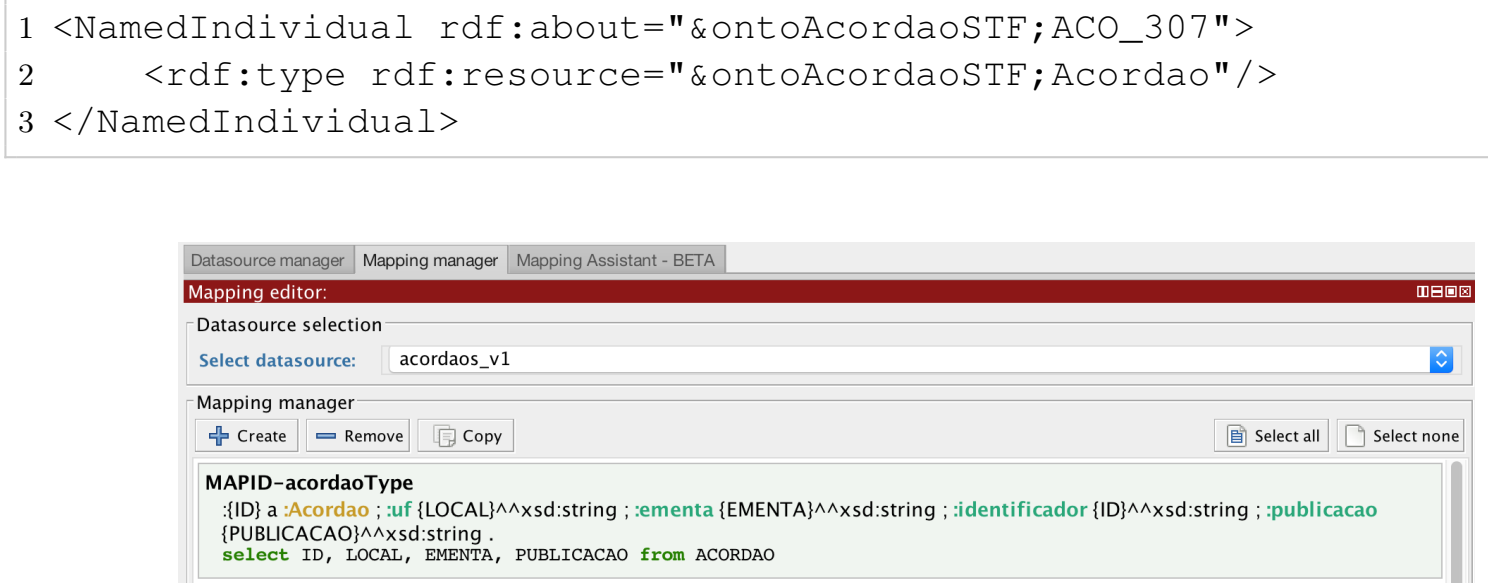

Figura 4.7: Aba do OntoP para gerenciamento dos mapeamentos

Os demais mapeamentos:

- :uf(LOCAL)^^xsd:string

- :ementa(EMENTA)^^xsd:string

- :identificador(IDENTIFICADOR)^^xsd:string

- :publicacao(PUBLICACAO)^^xsd:string

Definem as propriedades de dados do tipo string que um acórdão possui.

Por último, a terceira aba é a "Mapping Assistant", ilustrada na Figura 4.8, esta aba é um assistente que facilita a criação dos mapeamentos.

A Figura 4.8 demonstra a criação dos mapeamentos e é possível identificar os campos:

- Select Datasource: De onde é necessário escolher uma fonte de dados que tenha sido previamente configurada.

- Data Set: Depois de escolhido a fonte de dados é necessário escolher qual tabela será utilizada para a seleção dos campos e realização dos mapeamentos.

- Focus on URI e Mapping for class: A combinação destes dois campos permitem, após os campos terem sido selecionados, que sejam utilizados para mapeamentos entre as classes da ontologia. Exemplo: :(ID) a:Acordao.

- Focus on URI e add new property mapping: A combinação destes dois campos permitem a criação das propriedades de dados. Exemplo: :uf(LOCAL)^^^xsd:string

Esta fase de utilização do plugin OntoP, resultou em todos os mapeamentos necessários para que a ontologia JurisJFSP pudesse responder as questões de competência. Alguns dos mapeamentos resultantes estão ilustrados pelas Figuras 4.9, 4.10 e 4.11. 


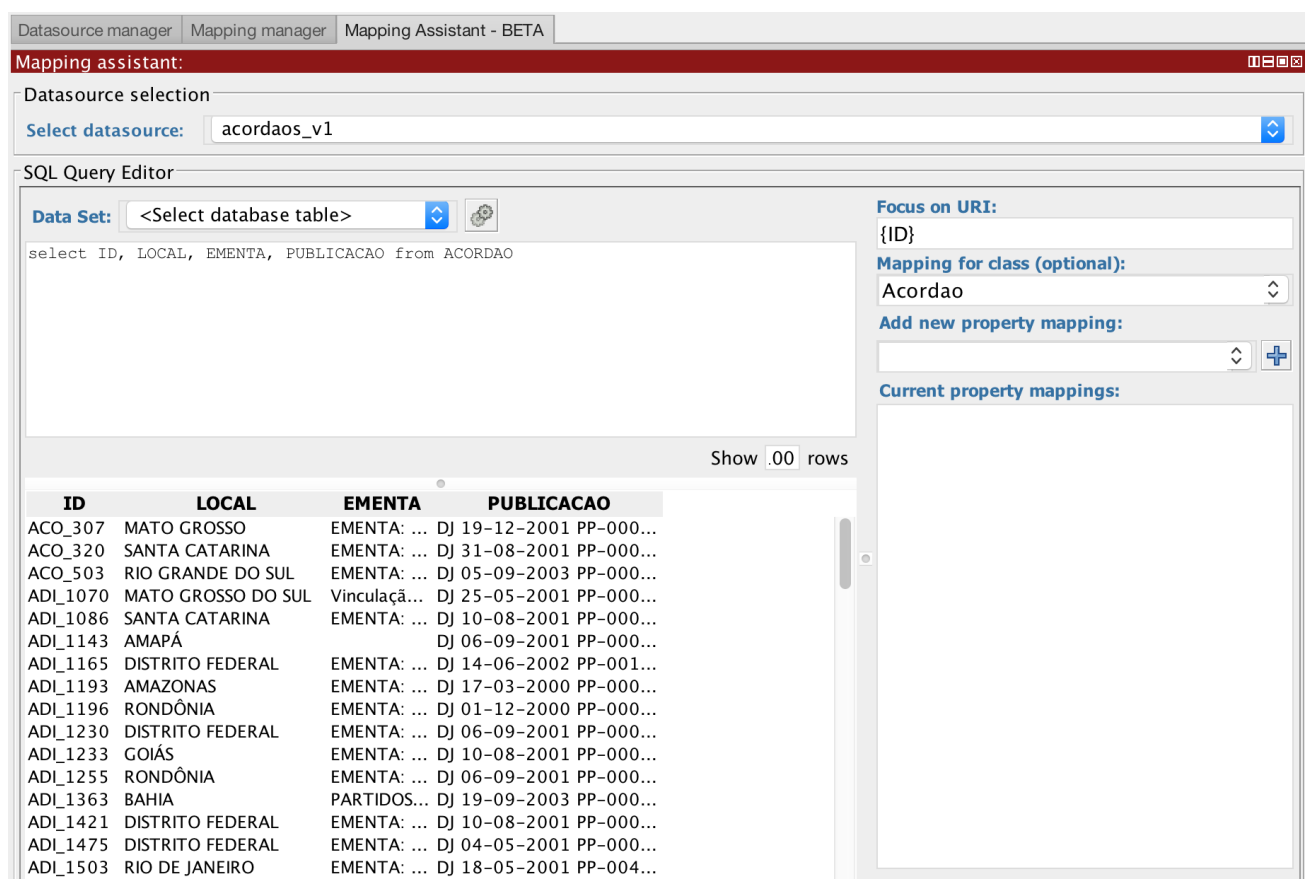

Figura 4.8: Aba do OntoP de assistência para criação dos mapeamentos

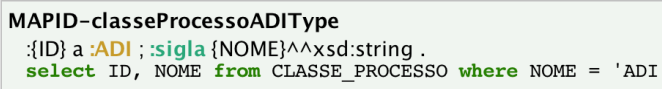

Figura 4.9: Mapeamento que define o atributo ID da tabela CLASSE_PROCESSO como uma Classe de Processo do tipo ADI

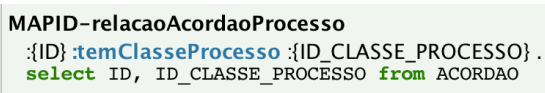

Figura 4.10: Mapeamento que define o relacionamento entre um Acórdão e uma Classe de Processo ADI

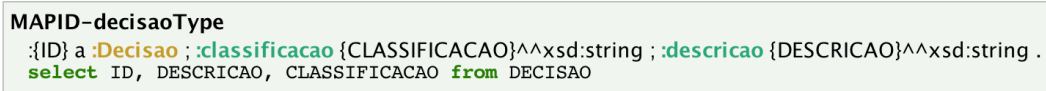

Figura 4.11: Mapeamento que define o atributo ID da tabela DECISAO como uma classe do tipo Decisao. Também são definidos as propriedades de dados "classificação" $e$ "descrição"

\subsubsection{Validação da Ontologia}

Para saber se a ontologia construída antende o escopo e se enquadra no domínio dos acórdãos do STF, ela deve responder as questões de competências formuladas anteriormente. Para isto foram criadas consultas utilizando a linguagem SPARQL.

Para realizar as consultas dos mapeamentos criados por meio do OBDA, no Protégé existe a aba "OntoP SPARQL". Por meio dela pode-se fazer consultas em SPARQL. As três consultas pré-configuradas são ilustradas pelas Figuras 4.12, 4.13 e 4.14 .

A consulta realizada na Figura 4.12 seleciona, por meio da instrução SELECT, os campos ?ministro_desafiador e ?acordao. Já a instrução WHERE filtra os resultados com base na inserção de triplas. Exemplo:

\section{- ?acordao rdf:type stf:Acordao}

- ?acordao stf:temVoto ?voto

- ?voto rdf:type stf:Voto 


\section{- ?voto stf:temRelator ?relator}

Com isto somente serão retornados acórdãos que possuam todas estas triplas.

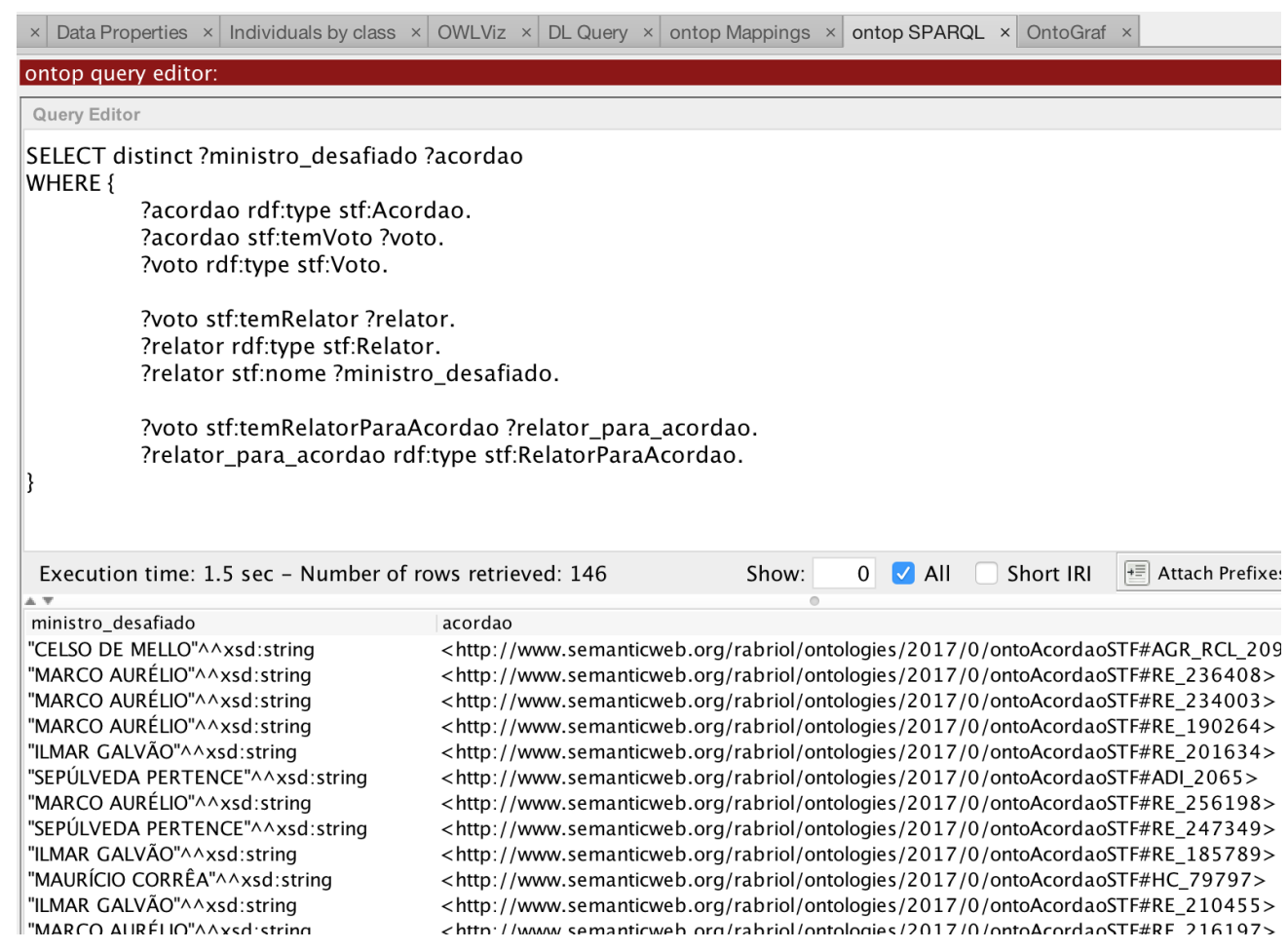

Figura 4.12: Consulta em SPARQL para a questão Quais ministros são desafiados?

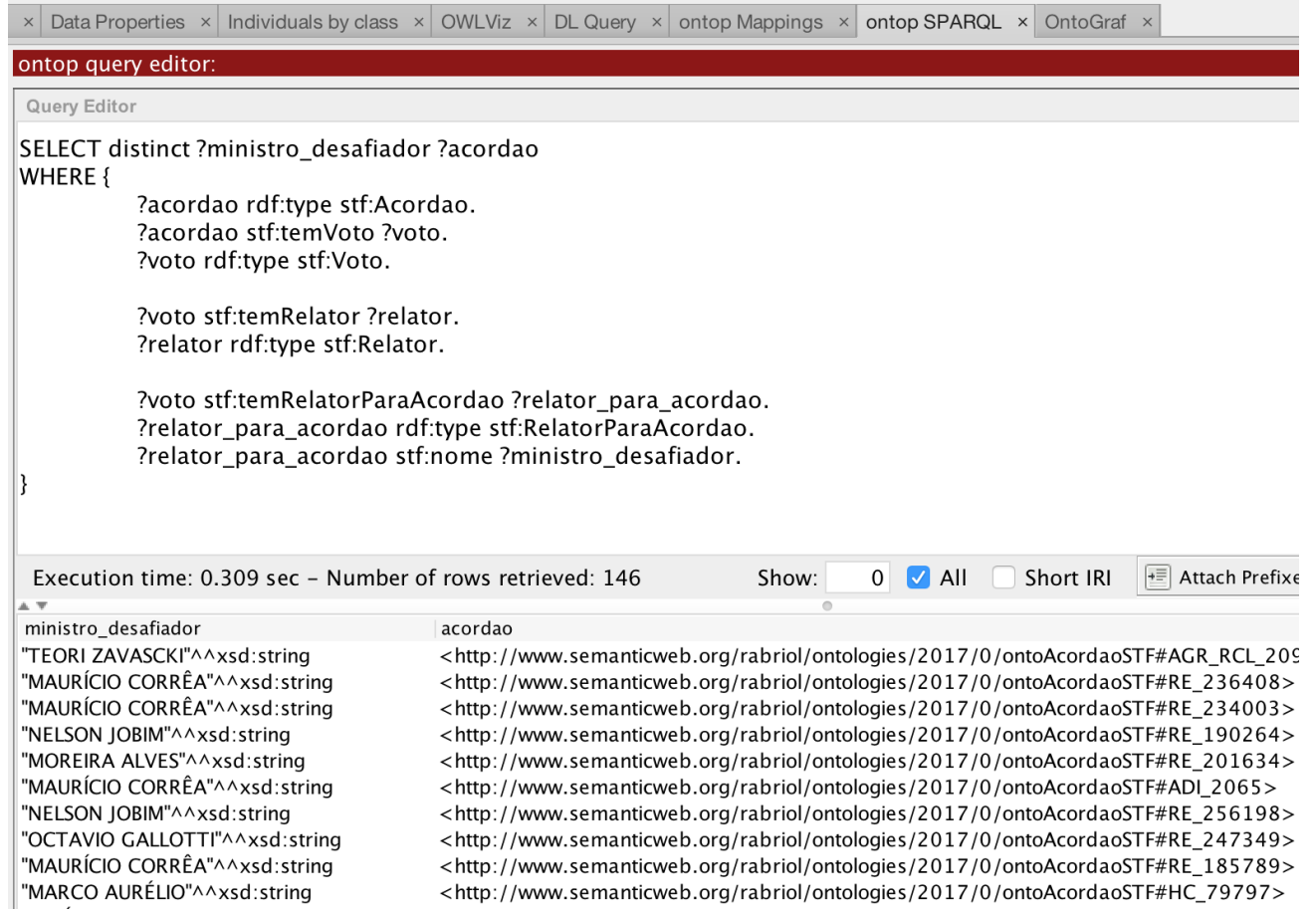

Figura 4.13: Consulta em SPARQL para a questão: Quais ministros são desafiadores? 
$\times$ Data Properties $\times$ Individuals by class $\times$ OWLViz $\times$ DL Query $x$ ontop Mappings $\times$ ontop SPARQL $\times$ OntoGraf $\times$
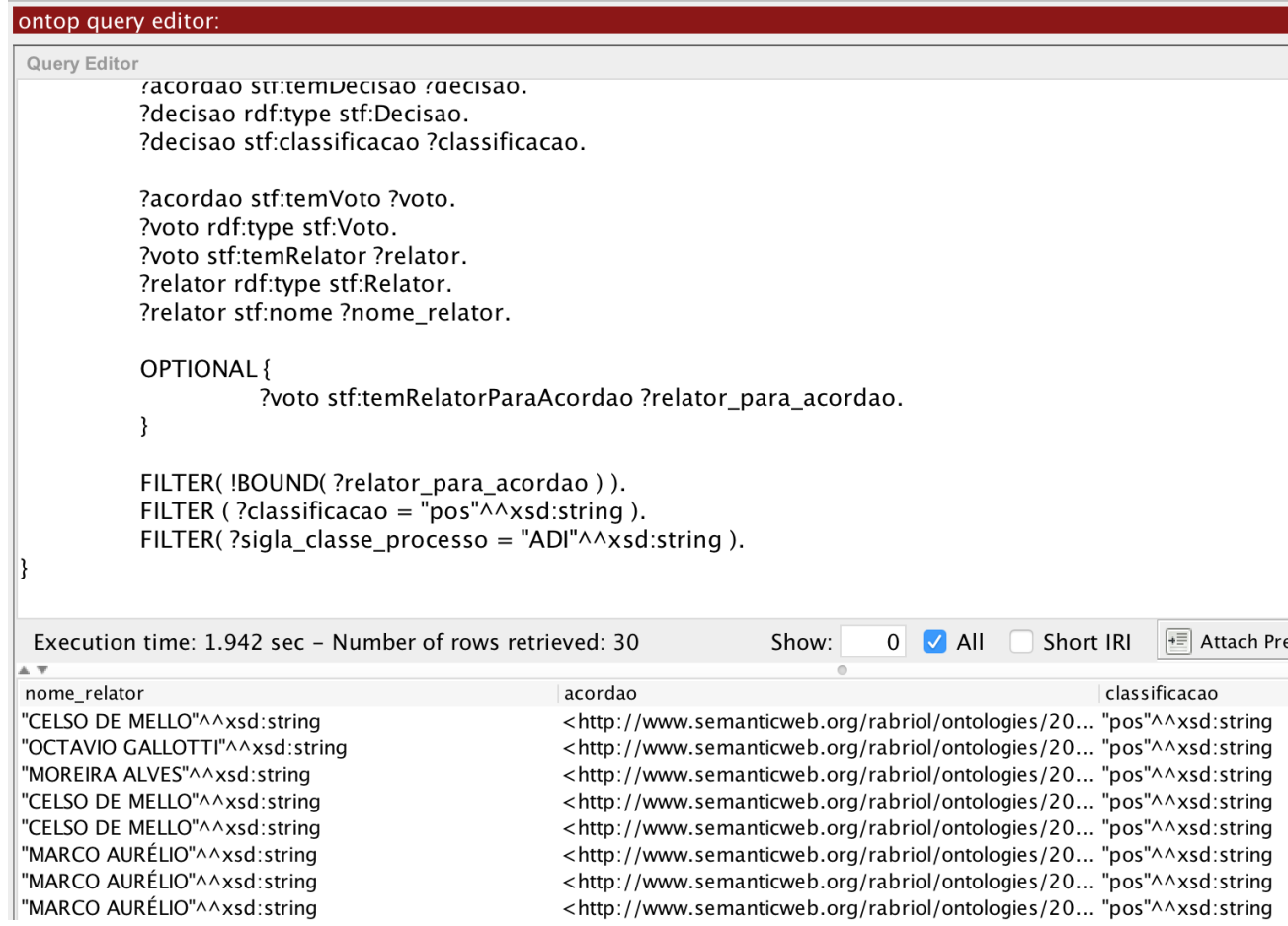

Figura 4.14: Consulta em SPARQL para a questão: Quais ministros enquanto relatores dão provimento para ação direta de inconstitucionalidade?

É possível validar que os dados retornados pelas consultas em SPARQL estão corretos, uma vez que as mesmas consultas podem ser feitas diretamente na base de dados original, porém como já comentado esta abordagem não é boa para representação de conhecimento. Realizar consultas diretamente na base de dados exige um conhecimento da estrutura das tabelas e como elas se relacionam. 


\section{Capítulo 5}

\section{Construção do Mecanismo de Consulta}

Neste capítulo será demonstrado o desenvolvimento final do mecanismo de consulta, dando continuidade ao que foi desenvolvido no capítulo anterior e acrescentando o desenvolvimento da interface do usuário e do mecanismo que interpreta as consultas realizadas pelo usuário e mapeia para as consultas correspondentes em SPARQL.

\subsection{Arquitetura do Mecanismo de Consulta}

Com as informações do banco de dados relacional mapeadas para a ontologia, a última etapa do desenvolvimento do mecanismo de busca, envolveu a utilização da linguagem Java ${ }^{1}$ e outras três tecnologias Regex ${ }^{2}$, Spring Framework ${ }^{3}$ e Angular ${ }^{4}$. O Java foi escolhida por ser a linguagem da biblioteca OWL API que o framework OntoP implementa. O framework Spring foi escolhido por facilitar todo o processo de receber as requisições do usuário e retornar os resultados. Já a tecnologia Angular foi utilizada para manipular os resultados e poder apresentar a informação de maneira mais adequada, como será demonstrado nos resultados finais. Com base então na linguagem Java e demais tecnologias foi desenvolvido o sistema conforme demonstrado na figura 5.1.

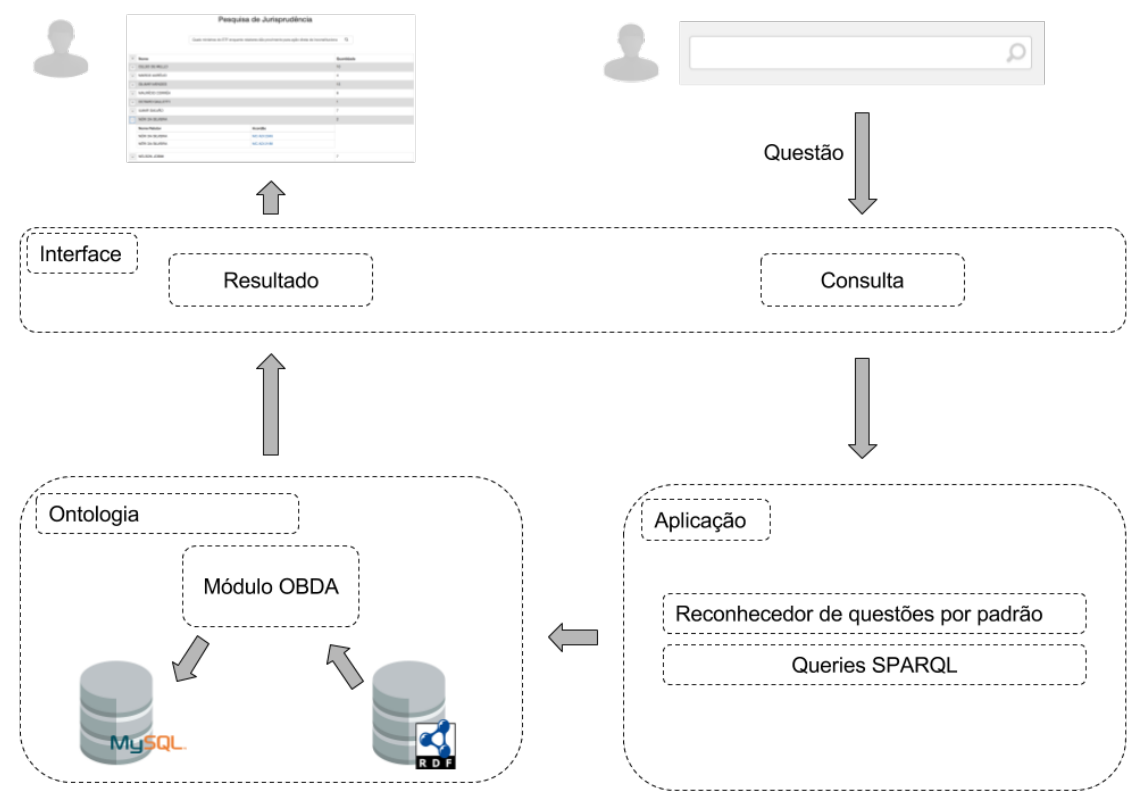

Figura 5.1: Arquitetura do mecanismo de busca para os acórdãos do STF utilizando ontologia

\footnotetext{
${ }^{1}$ https://www.java.com/pt_BR/about/whatis_java.jsp

${ }^{2}$ https://docs.oracle.com/javase/7/docs/api/java/util/regex/Pattern.html

${ }^{3}$ https://projects.spring.io/spring-framework/

${ }^{4}$ https://angularjs.org/
} 
Todo o código fonte do sistema construido, pode ser encontrado no endereço: https://github. $\mathrm{com} / \mathrm{rabriol} / \mathrm{stf}-$ ontology-search.

\subsubsection{Módulo de Interface do Usuário}

O primeiro módulo é o que realiza a interface de comunicação com o usuário, e é responsável por receber as consultas dos usuários na forma de linguagem natural, encaminhá-las para o segundo módulo o de aplicação e ao final do processo retornar ao usuário os resultados produzidos.

\subsubsection{Módulo de Aplicação}

No segundo módulo, o de aplicação, estão pré-configuradas 3 expressões regulares:

- [\wâãé ]*(ministro[s]*) [ \wâãé ]*(desafiado[s]*) ( (?!r))")

- Expressão regular que detecta as consultas: Quais ministros são desafiados?

- [\wâãé ]*(ministro[s]*) [ \wâãé ]*(desafiador[es]*) ( (?!s))

- Expressão regular que detecta as consultas: Quais ministros são desafiadores?

- [\wâãé ]*(relator[es]*)+[\wwâãé ]*(provimento[s]*)+[\wwâãé ]* $(\operatorname{sim})+[\backslash$ wwâãé ]*(ação direta de inconstitucionalidade) +

- Expressão regular que detecta as consultas: Quais ministros enquanto relatores dão provimento para ação direta de inconstitucionalidade?

Com base nestas expressões regulares, toda vez que o módulo de interface do usuário chama o módulo de aplicação repassando para ele a consulta realizada, este por sua vez, verifica qual das 3 expressões regulares se encaixa na consulta recebida. Por exemplo na consulta:

- Quais ministros são desafiados?

Após realizar o teste com todas as 3 expressões regulares, é identificado que a expressão regular que se encaixa na pergunta inserida é:

[ \wâãé ]*(ministro[s]*) [ \wâãé ]*(desafiador[es]*) ((?!s))

Esta expressão regular se encaixa na pergunta sobre os ministros desafiados, pois garante que de toda a frase deve haver o palavra ministro ou ministros e na sequência, mesmo sucedido por mais palavras, em algum momento deve aparecer a palavra desafiado ou desafiados. Com isto têm-se uma flexibilidade maior para detectar como o mesmo tipo de consulta, frases como:

- Quais são os ministros desafiados

- Quem são os ministros desafiados

- Ministros desafiados

- Os ministros desafiados

Pois em todas as consultas sempre há a presença dos termos ministros e desafiados. E esta mesma lógica é aplicada para as outras expressões regulares. 


\subsubsection{Módulo de Ontologia}

Após a identificação do tipo de consulta, esta é encaminhada para o módulo de ontologia, que irá realizar a consulta correspondente em SPARQL. As consultas em SPARQL foram previamente configuradas, ou seja para cada expressão regular criada existe uma consulta em SPARQL para responder a questão. Embora existam trabalhos com o objetivo de gerar as consultas SPARQL dinamicamente, estas técnicas não foram utilizadas neste trabalho.

A figura 5.2 apresenta a consulta em SPARQL correspondente a questão e nela é possível identificar algumas das entidades definidas pela ontologia, dentre elas: Acórdão, Voto, Ministro Relator e Ministro Relator para Acórdão. Estas entidades estão relacionadas quando se deseja obter quem são os ministros desafiados, pois quando em um Voto de um Acórdão, estão presente os papéis de Ministro Relator e Ministro Relator para Acórdão, significa que o ministro relator original foi desafiado pelo ministro relator para acórdão.

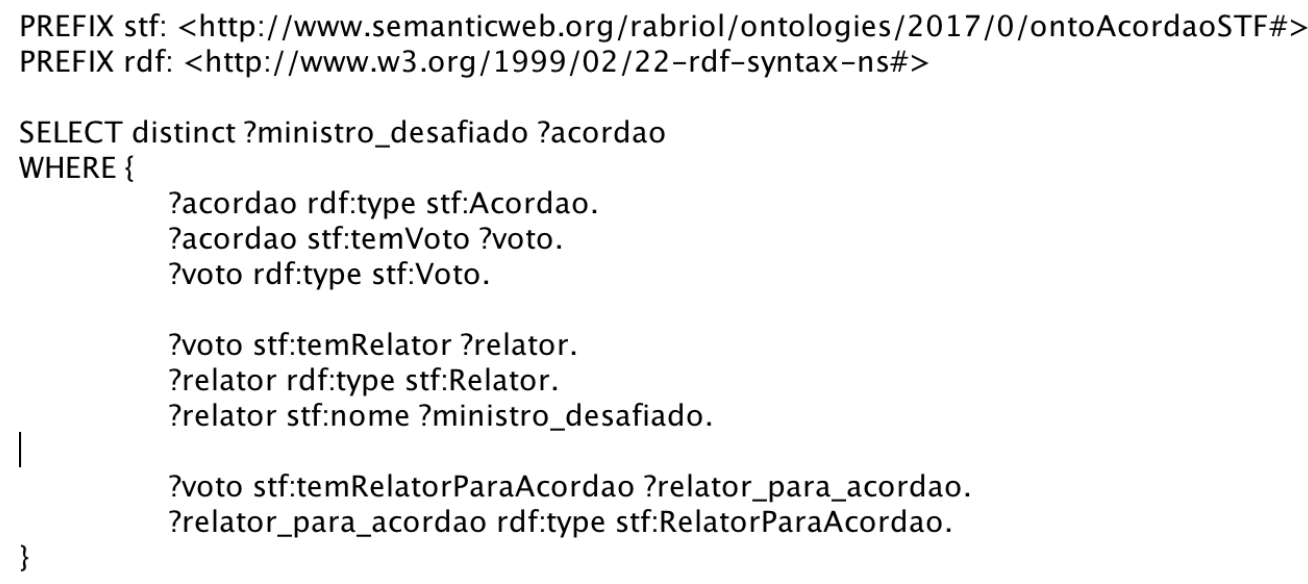

Figura 5.2: Consulta em SPARQL para a questão de competência "Quais ministros são desafiados?"

E por fim, após esta consulta, os resultados são apresentados para o usuário por meio do módulo de interface. 


\section{Capítulo 6}

\section{Resultados}

Neste capítulo serão apresentados os resultados finais obtidos e uma comparação entre o mecanismo que o STF disponibiliza e o que aqui foi desenvolvido.

\subsection{Pesquisa de Jurisprudência}

Nas Figuras 6.1, 6.2 e 6.3, podemos ver a interface do sistema implementado e as respostas às questões de competência.

\begin{tabular}{|c|c|c|c|}
\hline & & quais ministros são desafiados & a \\
\hline+ & \multicolumn{2}{|l|}{ Nome } & Quantidade \\
\hline+ & \multicolumn{2}{|l|}{ CÁRMEN LÚCIA } & 12 \\
\hline+ & \multicolumn{2}{|l|}{ CELSO DE MELLO } & 7 \\
\hline+ & \multicolumn{2}{|l|}{ MARCO AURÉLIO } & 334 \\
\hline+ & \multicolumn{2}{|l|}{ GILMAR MENDES } & 12 \\
\hline+ & \multicolumn{2}{|l|}{ RICARDO LEWANDOWSKI } & 17 \\
\hline+ & \multicolumn{2}{|l|}{ MAURÍCIO CORRÊA } & 22 \\
\hline+ & \multicolumn{2}{|l|}{ OCTAVIO GALLOTTI } & 16 \\
\hline+ & \multicolumn{2}{|l|}{ ILMAR GALVÃO } & 38 \\
\hline+ & \multicolumn{2}{|l|}{ NÉRI DA SILVEIRA } & 15 \\
\hline+ & \multicolumn{2}{|l|}{ NELSON JOBIM } & 8 \\
\hline+ & \multicolumn{2}{|l|}{ MOREIRA ALVES } & 3 \\
\hline
\end{tabular}

Figura 6.1: Resultado para questão "Quais ministros são desafiados?"

A coluna Quantidade presente em todas as respostas é simplesmente um detalhe de implementação da parte visual da aplicação, uma vez que é simples unir todos os acórdãos retornados com base no nome do Ministro. Com esta coluna porém, pode-se concluir com base na Figura 6.1 que o ministro mais desafiado é o ministro MARCO AURÉLIO e na Figura 6.2 o ministro mais desafiador é o ministro GILMAR MENDES. 
Pesquisa de Jurisprudência

quais ministros são desafiadores

\begin{tabular}{|l|l|l|}
\hline+ & Nome & Quantidade \\
\hline+ & RICARDO LEWANDOWSKI & 19 \\
\hline+ & MARCO AURÉLIO & 67 \\
\hline+ & JOAQUIM BARBOSA & 55 \\
\hline+ & DIAS TOFFOLI & 46 \\
\hline+ & TEORI ZAVASCKI & 1 \\
\hline+ & GILMAR MENDES & 95 \\
\hline+ & AYRES BRITTO & 5 \\
\hline+ & SEPÚLVEDA PERTENCE & 5 \\
\hline+ & MAURÍCIO CORRÊA & 51 \\
\hline+ & NELSON JOBIM & 45 \\
\hline+ & CELSO DE MELLO & 71 \\
\hline+ & CARLOS VELLOSO & 23 \\
\hline+ & ELLEN GRACIE & 12 \\
\hline
\end{tabular}

Figura 6.2: Resultado para a questão "Quais ministros são desafiadores?"

\section{Pesquisa de Jurisprudência}

\begin{tabular}{|c|c|c|c|}
\hline & & \multirow{2}{*}{\multicolumn{2}{|c|}{ Quais ministros do STF enquanto relatores dão provimento para ação direta de inconstituciona $\quad$ Q }} \\
\hline & & & \\
\hline+ & Nome & & Quantidade \\
\hline+ & CELSO DE MELLO & & 10 \\
\hline+ & MARCO AURÉLIO & & 4 \\
\hline+ & GILMAR MENDES & & 15 \\
\hline+ & MAURÍCIO CORRÊA & & 6 \\
\hline+ & OCTAVIO GALLOTTI & & 1 \\
\hline+ & ILMAR GALVÃO & & 7 \\
\hline- & NÉRI DA SILVEIRA & & 2 \\
\hline & Nome Relator & Acordão & \\
\hline & NÉRI DA SILVEIRA & MC ADI 2049 & \\
\hline & NÉRI DA SILVEIRA & MC ADI 2188 & \\
\hline+ & NELSON JOBIM & & 7 \\
\hline
\end{tabular}

Figura 6.3: Resultado para a questão "Quais ministros do STF, enquanto relatores, dão provimento sim para ações diretas de inconstitucionalidade?"

Também foi desenvolvida nesta aplicação a possibilidade de consultar diretamente o acórdão dado o nome de um ministro. Por exemplo, na Figura 6.3 ao clicar no Acórdão MC ADI 2188 é apresentada a tela conforme Figura 6.4. 

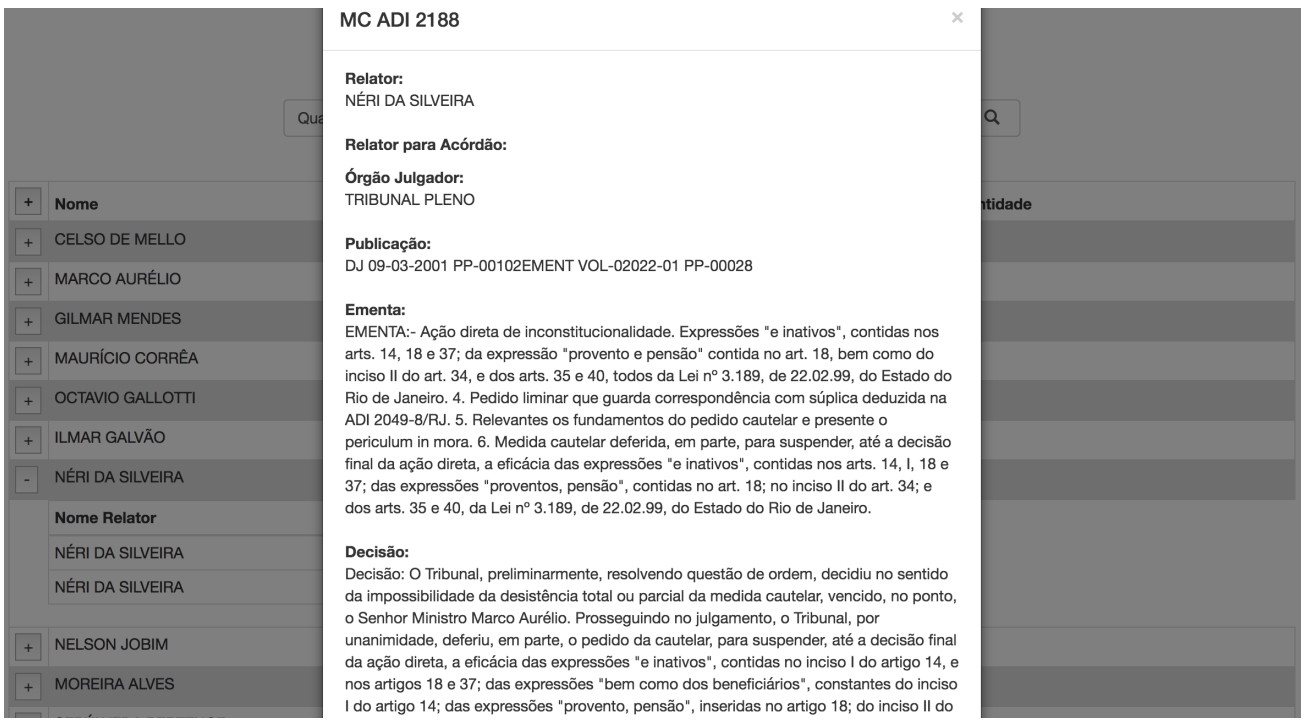

Figura 6.4: Acesso link direto para um Acórdão

\subsection{Mecanismo de Busca do STF}

Como abordado na introdução deste trabalho, o mecanismo de busca atual do STF apresenta uma busca em formato de questionário, onde uma série de campos devem ser preenchidos com o objetivo de filtrar o resultado desejado, mesmo assim os resultados não são precisos em relação ao que realmente foi pesquisado. Sendo assim, para mostrar que o mecanismo de consulta desenvolvido neste trabalho, apresenta melhores resultados em relação ao provido pelo STF, será tomado como exemplo a consulta:

- Quais ministros são desafiados?

Utilizando o mecanismo do STF, deve-se realizar a consulta conforme demonstrado pela Figura 6.5 .

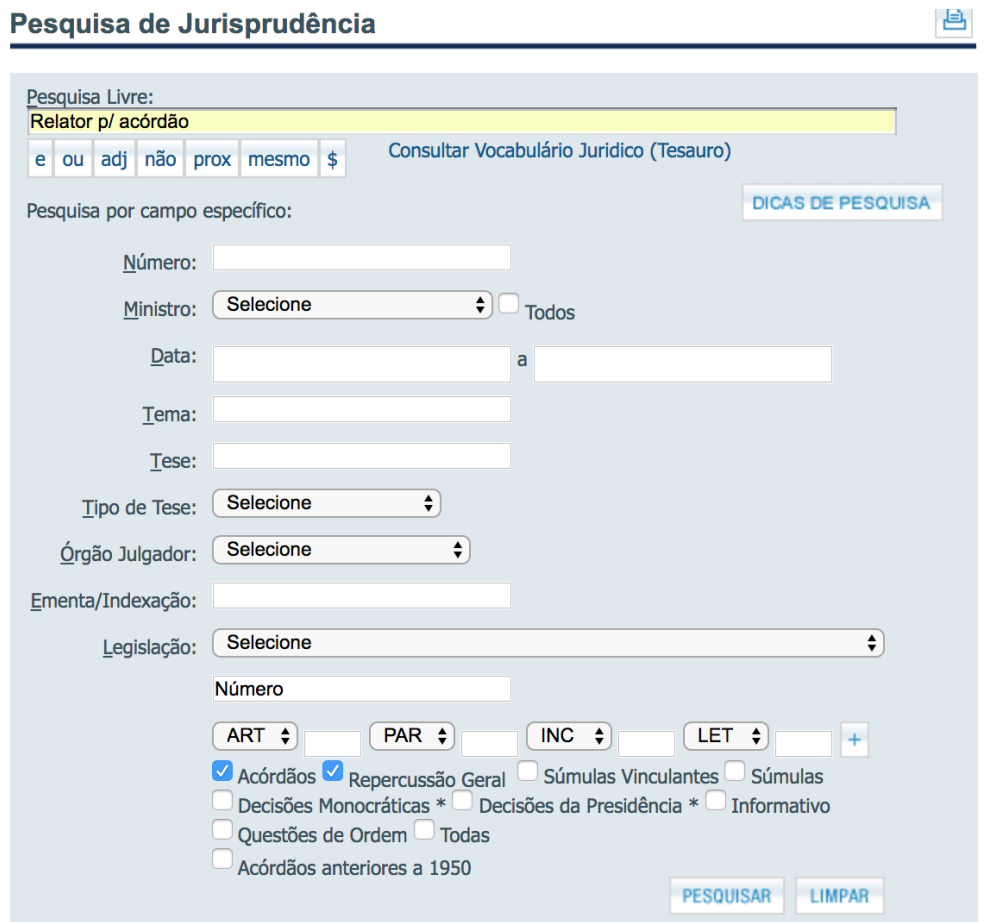

Figura 6.5: Mecanismo de busca do STF. Consulta: Quais ministros são desafiados? 
Como resultado desta busca, vemos na Figura 6.6 que foram retornados 246 acórdãos.

\begin{tabular}{l} 
Pesquisa de Jurisprudência \\
\hline Não encontrou o que procurava? Pesquisa novamente. \\
ACÓRDÃOS 246 documento(s) encontrado(s)
\end{tabular}

Figura 6.6: Resultado da busca utilizando mecanismo do STF

A partir deste resultado, é necessário um trabalho de separação manual onde é feita a identificação de acórdãos que contenham ministros no papel de Relator para Acórdão, como demonstrado na Figura 6.7. Pois mesmo sendo parte do mesmo conjunto de acórdãos retornados, há acórdãos que não contêm o papel de Relator para Acórdão o que indica que neste caso não houve nenhum desafio, é o que demonstra a Figura 6.8.

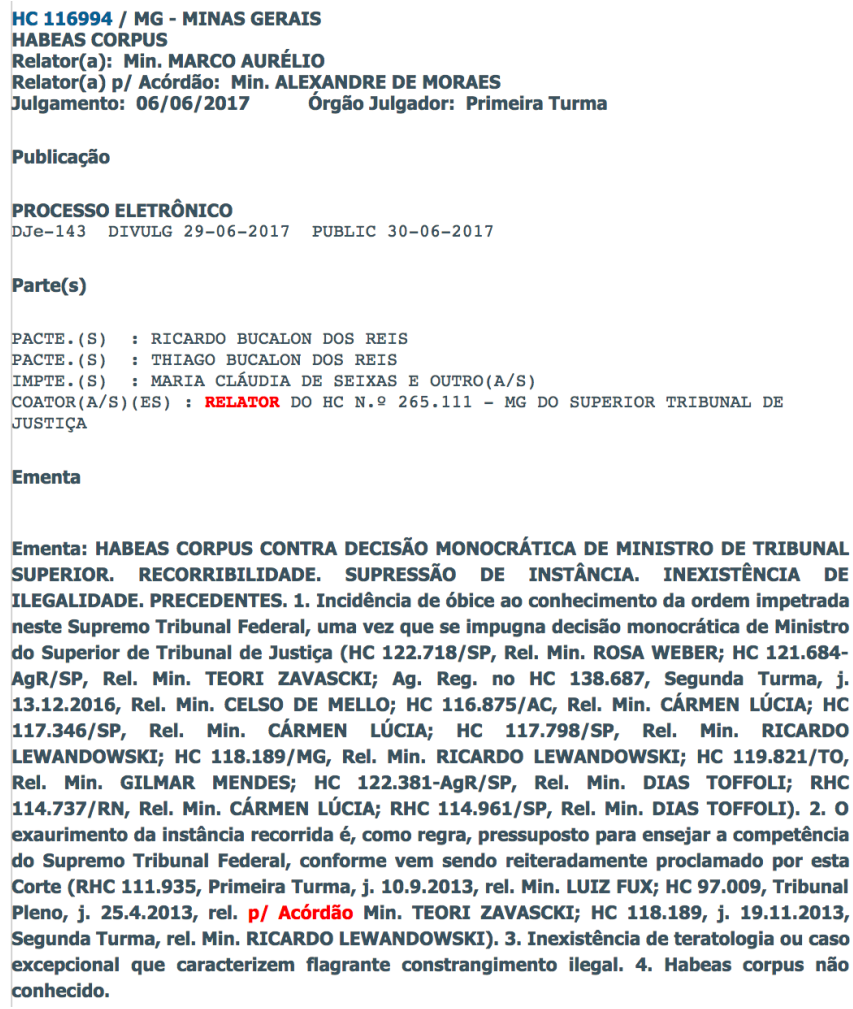

Figura 6.7: Acórdão contendo ministro no papel de Relator para Acórdão 


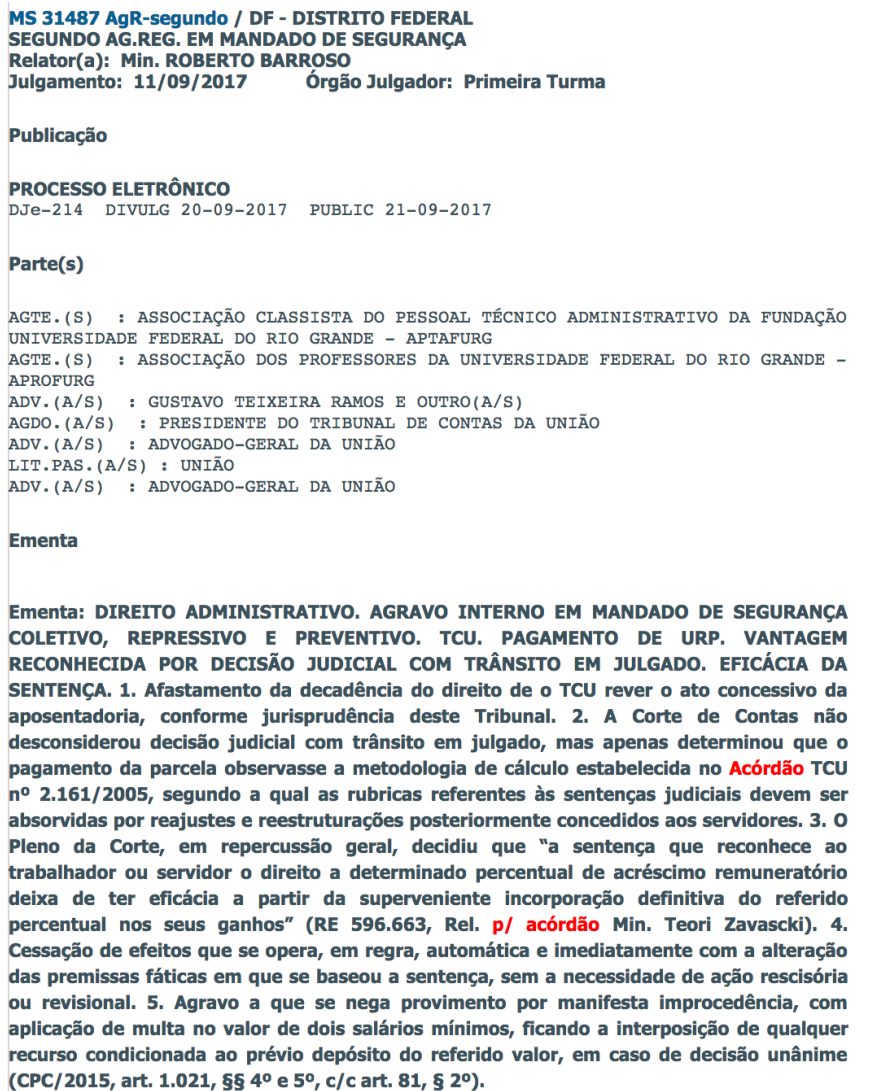

Figura 6.8: Acórdão parte do resultado de ministros desafiados mas que não contêm Relator para Acórdão

Em comparação dos resultados obtidos por meio do mecanismo de busca do STF, pode-se concluir que uma abordagem utilizando ontologias e OBDA apresenta resultados bem mais interessantes e precisos do ponto de vista do real sentido do que foi consultado. 


\section{Capítulo 7}

\section{Conclusões}

Neste trabalho foi proposta uma implementação prática de um mecanismo de busca, que por meio de tecnologias como ontologias e OBDA, visa melhorar a maneira como hoje são feitas as buscas por acórdãos do STF. A ontologia JurisJFES conforme proposta no trabalho Bourguet e Costa [2016], não possuia nenhuma implementação prática até o momento.

Desta forma espera-se que em continuidade a este trabalho o mecanismo de busca seja expandido para permitir que mais questões sejam respondidas, tais como:

- Quais decisões foram divergentes

- Quais decisões foram unânimes

- Em quais decisões divergentes houve condução do relator original

- Em quais decisões divergentes houve condução do relator para acórdão

Além disso, outro ponto que espera-se abordar em um trabalho futuro será suportar os documentos de acórdãos de outros órgãos além do STF como por exemplo o STJ.

Com relação a classificação automática das decisões, há a necessidade de melhorar a precisão do que se entende por decisão favorável e não favorável, pois em alguns casos uma decisão pode ser parcial e neste ponto classificar meramente como favorável e não favorável não representa muito bem o real sentido da decisão.

A forma como as consultas são interpretadas e mapeadas para consultas SPARQL correspondentes, também pode ser melhorada com a utilização de técnicas de processamento de linguagem natural e aprendizagem de máquina. 


\section{Referências Bibliográficas}

Bagosi et al.(2014) T. Bagosi, D. Calvanese, J. Hardi, S. Komla-Ebri, D. Lanti, M. Rezk, M. Rodríguez-Muro, M. Slusnys e G. Xiao. The Ontop Framework for Ontology Based Data Access. Springer. Citado na pág. xi, 13, 14

Borst(1997) Willem Nico Borst. Construction of Engineering Ontologies for Knowledge Sharing and Reuse. Tese de Doutorado, Universiteit Twente. Citado na pág. 7

Bourguet e Costa(2016) Jean-Rémi Bourguet e Melissa Zorzanelli Costa. About the Exposition of Brazilian Jurisprudences. Brazilian Ontology Research Seminar, Ontobras-2016, Curitiba. Citado na pág. xi, 16, 17, 39

Calò(2014) A. Calò. Extração e Análise de Informações Jurídicas Públicas. URL http://bcc.ime. usp.br/tccs/2014/sandro/Monografia.pdf, 2014. Trabalho de Conclusão de Curso, IME-USP, Data de acesso: 10 Outubro de 2017. Citado na pág. 15

Cintra et al.(2006) AC de A. Cintra, Ada Pellegrini Grinover e CR Dinamarco. Teoria Geral do Processo. Malheiros Editores. Citado na pág. 1

Falcão et al.(2011) J. Falcão, P. C. Cerdeira e D. W. Argueles. I Relatório Supremo em Números: O Múltiplo Supremo. URL http://www.fgv.br/supremoemnumeros/relatorios/i_relatorio_do_ supremo_em_numeros_0.pdf, 2011. Novas ideias em Direito, Resultados de Pesquisa, Data de acesso: $1 \overline{4}$ Janeiro de 2018 . Citado na pág. 1

Giaretta e Guarino(1995) P. Giaretta e N. Guarino. Ontologies and Knowledge Bases Towards a Terminological Clarification. Towards very large knowledge bases: knowledge building 83 knowledge sharing, 25:32. Citado na pág. 7

Gruber(1995) T. R. Gruber. Toward Principles for the Design of Ontologies Used for Knowledge Sharing. International Journal of Human-Computer Studies, 43(5):907-928. Citado na pág. 7

Grüninger e Fox(1995) Michael Grüninger e Mark S. Fox. Methodology for the Design and Evaluation of Ontologies. Proceedings of the Workshop on Basic Ontological Issues in Knowledge Sharing, IJCAI-95, Montreal. Citado na pág. 19

Guarino(1998) N. Guarino. Formal Ontology in Information Systems: Proceedings of the First International Conference (FOIS'98), June 6-8, Trento, Italy, volume 46. IOS press. Citado na pág. 7

Guizzardi(2000) G. Guizzardi. Desenvolvimento para e com Reuso: um Estudo de Caso no Domínio de Vídeo Sob Demanda. Dissertação de Mestrado, Universidade Federal do Espírito Santo. Citado na pág. xi, 8,10

Haav e Lubi(2001) H. M. Haav e T. L. Lubi. A Survey of Concept-Based Information Retrieval Tools on the Web. PROCEEDINGS OF EAST-EUROPEAN CONFERENCE ADBIS. Citado na pág. 8 
Hebeler et al.(2011) J. Hebeler, M. Fisher, R. Blace e A. Perez-Lopez. Semantic Web Programming. John Wiley \& Sons. Citado na pág. 11

Horridge et al.(2009) M. Horridge, S. Jupp, G. Moulton, A. Rector, R. Stevens e C. Wroe. A Practical Guide to Building OWL Ontologies Using Protégé 4 and CO-ODE Tools Edition1. 2. The University of Manchester. Citado na pág. 12

Jasper e Uschold(1999) R. Jasper e M. Uschold. A Framework for Understanding and Classifying Ontology Applications. IJCAI-99, ONTOLOGY WORKSHOP. Citado na pág. 8

Mendonça(2015) F. M. Mendonça. Ontoforinfoscience: Metodologia para Construção de Ontologias pelos Cientistas da Informação. Dissertação de Mestrado, Espírito Santo. Citado na pág. 8

Miller(1998) E. Miller. An Introduction to the Resource Description Framework. Bulletin of the American Society for Information Science and Technology, 25. Citado na pág. 10

Mizoguchi et al.(1995) R. Mizoguchi, M. Ikeda, K. Seta e J. Vanwelkenhuysen. Ontology for Modeling the World from Problem Solving Perspectives. Proc. of IJCAI-95 WS on Basic Ontological Issues in Knowledge Sharing, páginas 1-12. Citado na pág. 8

Morais e Ambrósio(2007) E. A. M. Morais e A. P. L. Ambrósio. Ontologias: Conceitos, Usos, Tipos, Metodologias, Ferramentas e Linguagenss. URL http://www.portal.inf.ufg.br/sites/default/ files/uploads/relatorios-tecnicos/RT-INF_001-07.pdf, 2007. Relatório Técnico-RT-INF-001/07, Data de acesso: 10 Outubro de 2017. Citado na pág. xi, 10

Rish(2001) Irina Rish. An empirical study of the naive bayes classifier. Em IJCAI 2001 Workshop on Empirical Methods in Artificial Intelligence, volume 3, páginas 41-46. IBM New York. Citado na pág. 21

Sampaio(2015) T. F. J. Sampaio. Introdução ao Estudo do Direito. Forense. Citado na pág. 2

Seaborne et al.(2007) A. Seaborne, G. Manjunath, C. Bizer, J. Breslin, S. Das, I. Davis, S. Harris, K. Idehen, O. Corby e K. Kjernsmo. SPARQL/Update: A Language for Updating RDF Graphs. URL http://www.hpl.hp.com/techreports/2007/HPL-200\%-102.pdf, Data de acesso: 10 Outubro de 2017, 15. Citado na pág. 13

Silva(2015) V. A. Silva. Um Voto Qualquer?' O Papel do Ministro Relator na Deliberação do Supremo Tribunal Federal. URL https://estudosinstitucionais.com/REI/article/view/21, 2015. Revista de Estudos Institucionais, Vol.1,1, Data de acesso: 14 Janeiro de 2018. Citado na pág. 2

Uschold e Gruninger(1996) M. Uschold e M. Gruninger. Ontologies: principles, methods an applications. knowledge engineering review. Citado na pág. 8

W3C(2012) W3C. OWL 2 Web Ontology Language Primer (Second Edition), 2012. URL https: //www.w3.org/TR/2012/REC-owl2-primer-20121211/. Data de Acesso: 10 outubro. 2017. Citado na pág. 12 